\title{
Asking About Numbers: Why and How*
}

\author{
Stephen Ansolabehere \\ Harvard University \\ sda@gov.harvard.edu
}

\author{
Marc Meredith \\ University of \\ Pennsylvania \\ marcmere@sas.upenn.edu
}

\author{
Erik Snowberg \\ California Institute \\ Technology \\ snowberg@caltech.edu
}

November 13, 2011

\begin{abstract}
Survey questions about quantities offer a number of advantages over more common qualitative questions. However, concerns about survey respondents' abilities to accurately report numbers have limited the use of quantitative questions. This paper shows quantitative questions are feasible and useful for the study of economic voting. First, survey respondents are capable of accurately assessing familiar economic quantities, such as the price of gas. Second, careful question design - in particular providing respondents with benchmark quantities - can reduce measurement error due to respondents not understanding the scale on which more complex quantities, such as the unemployment rate, are measured. Third, combining quantitative and qualitative questions sheds light on where partisan bias enters economic assessments: in perceiving, judging, or reporting economic quantities. The evidence indicates bias enters the reporting of assessments, and that this bias is smaller in quantitative questions than qualitative questions.
\end{abstract}

${ }^{*}$ We thank Mike Alvarez, Conor Dowling, Ray Duch, Jon Eguia, Ken Scheve, Emily Thorson, and Chris Wlezien for encouragement and suggestions, and seminar audiences at Columbia, MIT, MPSA, NYU, Temple, Wharton and Yale for useful feedback and comments. 


\section{Introduction}

Knowledge of the economy is important to a broad range of decisions: from private decisions, like investment and educational choices, to public decisions, such as voting for bond issues or holding the President accountable for his economic policy choices. Economic information is often expressed in numbers, for example, prices, rates, and even consumer confidence. Yet there is very little public opinion research on what citizens know about economic quantities, and how they use that knowledge to make decisions. ${ }^{1}$

This lack of research is perplexing, as theories of economic voting are fundamentally rooted in numbers. In particular, the political economy literature focuses on how vote shares change with economic quantities such as GDP growth, the unemployment rate, or inflation (e.g. Kramer (1971); Fair (1978); Alesina, Londregan and Rosenthal (1993)). Parallel investigations by survey researchers, however, have not yielded a set of findings that can be readily linked to statistical models used in analyses of such aggregate data. ${ }^{2}$ A fundamental cause of this disconnect is that survey researchers tend to rely on respondents' qualitative evaluations of the economy, rather than ask about quantities directly. Thus, developing standard questions to measure perceptions of economic quantities is essential for testing theories of economic voting. Our goal is to take a first step towards developing such standard questions by evaluating survey questions that directly ask about quantities.

This paper shows that survey respondents provide accurate responses to questions about familiar quantities, such as the price of gas. Moreover, we show that careful question design can reduce problems associated with quantitative questions when asking about more complex quantities, such as the unemployment rate. Finally, we show that quantitative questions seem to exhibit less partisan bias than qualitative questions. That is, this paper summarizes

\footnotetext{
${ }^{1}$ Quantities are relevant for a wide range of policy areas: for example: average test scores, incarceration rates, abortion rates, and healthcare expenditures.

${ }^{2}$ For example, whether voting is based on aggregate economic outcomes or a voter's personal economic outcomes (whether voters are sociotropic or egotropic, see Kinder and Kiewiet, 1979; 1981) does not affect patterns in aggregate data because, on average, personal outcomes improve when aggregate outcomes improve.
} 
the advantages of, and concerns about, quantitative questions, and makes some progress in alleviating those concerns.

For the past 30 years, the standard survey question used to measure economic evaluations and study economic voting has been some variant of the retrospective economic evaluation:

Now thinking about the economy in the country as a whole, would you say that over the past year, the nation's economy has gotten better, stayed about the same, or gotten worse?

There are a number of advantages to such qualitative questions. No sophisticated knowledge of economics is required to understand or respond to this question. It is also broad, allowing researchers to measure economic perceptions with a single question. Finally, this question is easily portable across surveys, facilitating comparisons across both time and space about the relationship between economic assessments and political behavior.

These advantages, however, come with some costs. The retrospective economic evaluation does not relate to a specific dimension of the economy - for example, GDP growth, levels of employment, tax policy, or changes in prices (inflation). Such vagueness invites projection of attitudes other than economic understanding, such as political beliefs. It also reduces complex economic assessments to one of three possible answers. ${ }^{3}$ Finally, this question cannot separate a respondent's perception of economic conditions on several dimensions from his or her judgment of whether those perceived conditions represent an improvement.

While quantitative questions are not perfect, they have a distinct conceptual advantage over qualitative questions. Namely, they can be used to ask respondents about the basic building blocks of many theories: quantities. However, quantitative questions remain largely unused due to concerns about whether respondents are capable of understanding and reporting quantities. Previous work generally finds that a substantial number of people report wildly inaccurate views about quantities such as the unemployment rate or inflation

\footnotetext{
${ }^{3}$ Many election surveys also let respondents also choose between "somewhat" and "substantially" better and worse.
} 
(Conover, Feldman and Knight, 1986; Holbrook and Garand, 1996; Blendon et al., 1997; Curtin, 2007). However, if a majority of voters are indeed unable to understand economic quantities, this calls into question the assumptions on which most political economic models are built.

In order to show respondents can handle numbers, we examine their assessments of the price of gas. Gasoline expenditures are a sizable portion of most households' budgets, and the price of gas is frequently encountered in respondents' everyday environment. Thus, inaccurate reports of the price of gas would suggest there are few quantities respondents can accurately report. However, in three different election surveys run since 2006, individuals accurately report the average price of gas. Moreover, there are few observable characteristics that consistently relate to either the bias or accuracy of reported gas prices. One characteristic that does make individuals more accurate is exposure to gas prices - for example, through driving - which is consistent with the idea that survey respondents are capable of reporting quantities with which they are familiar.

Asking about more complex quantities requires more care. In particular, we advocate the use of benchmarks to describe the scale on which the quantity of interest is measured. For example, most respondents are infrequently exposed to the unemployment rate, if at all, and thus provide very inaccurate assessments. A potential reason that is discussed in the literature for this inaccuracy is that not all respondents share a common understanding of what is meant by the unemployment rate, and hence that they are not reporting unemployment rates on the same scale. We show that providing respondents with the historical range and average level of the unemployment rate reduces differences in reported rates between higher and lower socioeconomic-status respondents. This is consistent with benchmarks reducing inaccurate responses caused by differential understandings of the scale on which economic quantities are measured.

In contrast to reported gas prices, many observable characteristics systematically associate with respondents' reports of the unemployment rate. Consistent with the mecro- 
economic voting theory of Ansolabehere, Meredith and Snowberg (2011a), we show in four election surveys in three different years that observable characteristics associated with a higher risk of unemployment increase reported unemployment rates. Moreover, reported unemployment rates rose in lockstep with the actual unemployment rate between 2008 and 2009.

Finally, we demonstrate that quantitative questions can help us to better understand the sources of partisan differences in responses to qualitative questions (Wlezien, Franklin and Twiggs, 1997; Anderson, Mendes and Tverdova, 2004; Evans and Andersen, 2006; Evans and Pickup, 2010). Combining information about economic perceptions with qualitative evaluations allows us to infer the criteria respondents use to judge economic performance. Our results indicate that partisan differences result from biases in the reporting of economic assessments, whether quantitative or qualitative. Moreover, quantitative questions evince less partisan bias than corresponding qualitative questions.

\section{Why Ask About Quantities?}

It is perhaps surprising that public opinion research focuses on qualitative - rather than quantitative - survey questions, given that many theories are rooted in numbers. For example, the theory of economic voting, and aggregate level studies about it, primarily focus on how political support for the incumbent party changes with various economic quantities, such as GDP growth, the unemployment rate, and inflation (Kramer, 1971; MacKuen, Erikson and Stimson, 1992; Erikson, MacKuen and Stimson, 2002; van der Brug, van der Eijk and Franklin, 2007). However, public opinion research into the individual-level mechanisms of economic voting has focused on the qualitative, retrospective economic evaluation discussed in the introduction. Supporting this focus are concerns that quantitative questions are too cognitively difficult for survey respondents.

This section details the potential advantages of quantitative questions. We then explore 
the concerns that have prevented a wider adoption of quantitative questions, and briefly preview how our research addresses these concerns through the careful design of quantitative questions.

\subsection{Benefits of Quantitative Questions}

Quantitative questions have four main advantages over qualitative questions. Quantitative questions allow researchers to separate respondents' perceptions of conditions from their judgments of those perceptions; they allow open responses; allow perceptions to be compared with actual conditions; and place respondents' responses on a standard scale.

Theories of economic voting posit that voters form perceptions of economic performance, and then judge these perceptions relative to some benchmark. ${ }^{4}$ Quantitative questions allow researchers to separately elicit information about these two steps. Without good measures of economic perceptions, researchers risk both incorrectly calculating the amount of economic voting, and a poor understanding of the mechanisms underlying it (Kramer, 1983; Wlezien, Franklin and Twiggs, 1997; Anderson, Mendes and Tverdova, 2004; Evans and Andersen, 2006; Evans and Pickup, 2010). Moreover, evaluations of complex issues, like the economy, are often multi-dimensional (Zaller and Feldman, 1992). As economic quantities are very specific, quantitative questions allow researchers to measure perceptions of the economy on multiple dimensions, and, in combination with a respondent's overall, qualitative evaluation, understand how these multiple perceptions are judged.

A second advantage of quantitative questions is that response is open - that is, response options can be relatively unconstrained. In contrast, qualitative questions are often closedthat is, constrained - to keep responses relevant and to reduce the cost of coding answers (Schuman and Presser, 1981). ${ }^{5}$ Open questions offer two advantages over closed questions. First, responses to closed questions are affected by the presentation and choice of response

\footnotetext{
${ }^{4}$ The benchmark may be a fixed standard in retrospective voting models, or depend on perceptions of opposition candidates in prospective models.

${ }^{5}$ It is possible to construct hybrid questions that put verbal labels on specific quantities or ranges of quantities. See Juster (1966) for an example.
} 
categories (Schwarz et al., 1985; Rockwood, Sangster and Dillman, 1997). Second, closed questions limit the amount of variation in responses (Groves et al., 2004). For example, individuals who perceive the unemployment rate to be $7 \%$ and $10 \%$, respectively, may both report that the economy has "gotten worse", even though those who think it is $10 \%$ believe there is almost $50 \%$ more unemployment. In practice this may result in a large loss of variation: on the 2008 American National Election Survey (ANES), 90\% of respondents reported that the economy had "gotten worse". Moreover, increasing the amount of variation captured by survey responses is particularly useful in understanding how economic information affects economic perceptions (Manski, 2004). ${ }^{6}$

Third, as quantitative questions often have an objectively correct answer, researchers can compare respondents' answers with actual conditions. For example, Hetherington (1996) shows that more media consumption is associated with worse economic evaluations. However, this study could not determine which group is more or less accurate in its perceptions. ${ }^{7}$ This contrasts with Ansolabehere, Snowberg and Snyder (2005) which uses quantitative questions to show that low media consumption is associated with more accurate perceptions of the amount of money spent in congressional campaigns.

A fourth advantage of quantitative questions is that they facilitate comparisons across respondents. Survey respondents are likely to differ in their interpretations of what is meant by verbal phrases (Beyth-Marom, 1982; Wallsten, 1986; Wright, Gaskell and O'Muircheartaigh, 1994). For example, research shows wide variation in the numerical interpretations of various verbal expressions of uncertainty: the probability assigned to the term "likely" varies from $42 \%$ at the 10 th percentile to $81 \%$ at the 90 th percentile (Beyth-Marom, 1982). Such interpretation differences may cause two individuals with identical underlying perceptions to give different answers to qualitative questions. In contrast, quantities like gas prices and

\footnotetext{
${ }^{6}$ This potential variation, however, may not be fully utilized as respondents tend to choose focal numbers, like multiples of five, when reporting quantities (Tourangeau and Smith, 1996; Tourangeau et al., 1997).

${ }^{7}$ Qualitative questions are occasionally used to identify inaccurate perceptions. For example, Bartels (2002) shows that a substantial percentage of respondents on the 1988 ANES report that inflation got worse over the course of the Reagan administration, when, objectively, inflation was significantly lower at the end of Reagan's term than at the beginning.
} 
the unemployment rate are measured on a well defined scale.

\subsection{Can Survey Respondents Handle Numbers?}

Despite these potential advantages, quantitative questions are infrequently used on political surveys. $^{8}$ The focus on qualitative questions comes largely from concerns that quantitative questions are too cognitively complex for survey respondents. This concern manifests itself in a number of ways: from a general perception that survey respondents cannot "handle" or do not like quantitative questions, to more specific mechanisms about how these cognitive costs create biases in responses. Additionally, the fact that quantitative questions put responses on a common scale can turn from asset to hindrance if respondents have different understandings of that scale. ${ }^{9}$

General concerns that quantitative questions are too cognitively demanding are found in research showing that survey respondents report wildly inaccurate assessments of quantities such as the population of minority groups, or the percentage of the federal budget spent on welfare and foreign aid (Nadeau, Niemi and Levine, 1993; Kuklinski et al., 2000; Gilens, 2001). Moreover, respondents indicate a preference for communicating numerical values qualitatively rather than quantitatively, although there is some heterogeneity (Erev and Cohen, 1990; Wallsten et al., 1993). Together, these findings question individuals' abilities to accurately report numbers (see Moxey and Sanford, 2000 for a summary).

Even if respondents are capable of providing numerical assessments, there are concerns that they may not have the motivation to do so. While motivation is a general problem in survey research, two factors make the problem more acute when asking about quantities. First, survey satisficing - the behavioral pattern of providing acceptable, rather than optimal, answers - increases when assessments are difficult to perform and report (Krosnick, 1991). Moreover, some respondents feel compelled to provide answers to factual questions,

\footnotetext{
${ }^{8}$ Quantitative questions are more frequently used on economic surveys. For example, the Michigan Survey of Consumer Behavior asks both quantitative and qualitative questions about inflation expectations.

${ }^{9}$ We advocate the use of benchmarks to put respondents on a common scale; see Section 4.
} 
rather than stating they "don't know" (Nadeau and Niemi, 1995). If these respondents lack the motivation to produce responses that accurately reflect their perceptions, then these additional answers may introduce unwanted noise. ${ }^{10}$ For example, Bruine de Bruin et al. (2000) find that survey respondents reporting a probability of 0.5 are often expressing general uncertainty, rather than a belief of a $50 \%$ chance.

Despite these concerns, we find in Section 3 that when respondents are asked about quantities they have direct experience with, such as gas prices, their responses are extremely accurate. This contradicts the hypothesis that survey respondents are generally unable to report numbers, either because they are incapable or because they lack motivation. Yet, there still may be concerns that certain types of individuals, like those with less education, may find it difficult to accurately report quantities. However, few covariates systematically associate with the accuracy of gas prices assessments. Thus, there appears to be widespread ability to accurately report familiar economic quantities.

\subsection{Do Respondents Really use a Common Scale?}

An advantage of quantitative questions is that they may put survey responses on a common scale. A common scale is useful as it allows researchers to interpret higher reported unemployment rates as higher perceptions of unemployment. ${ }^{11}$ However, this interpretation may not be valid if respondents are unfamiliar with the scale on which a quantity is measured. Indeed, $23 \%, 34 \%$, and $40 \%$ of respondents report that they have never heard of the unemployment rate, Consumer Price Index, and Gross Domestic Product, respectively (Curtin, 2007). Moreover, the percentage of low socio-economic status (SES) respondents who do

\footnotetext{
${ }^{10} \mathrm{On}$ the other hand, if quantitative questions motivate respondents to produce accurate responses because they know there is a wrong answer, this may be an added benefit of quantitative questions. Bullock, Gerber and Huber (2010) finds that providing financial incentives reduces, but does not eliminate, partisan differences in reported perceptions of facts.

${ }^{11}$ Moreover, if subjects perceive a scale linearly, then those that report $10 \%$ unemployment can be interpreted as perceiving twice as much unemployment as those that report $5 \%$ unemployment. However, as none of our discussion requires a linear scale, we discuss our results in terms of the weaker condition of a monotonic, but not necessarily linear, common scale.
} 
not know these quantities is substantially larger. ${ }^{12}$ This leads to concerns that heterogeneity in respondents' reports of technical economic quantities may be due to different levels of knowledge about the definition of those quantities, rather than different perceptions of the conditions that underly those quantities.

Although Section 4 shows this concern is valid, the same section also shows that careful question design produces patterns consistent with respondents using a common scale. In particular, we show that by providing benchmarks in questions about quantities - in this case, information on the historical tendencies of the unemployment rate-reduces both the number of outlying responses, and differences between the reports of higher and lower socioeconomic status respondents. This is consistent with benchmarks producing a common scale for all respondents.

A final concern is whether there is useful information in respondents' assessments of quantities. While this is a tricky question to answer, we present a variety of evidence demonstrating that reported economic quantities do reflect perceptions of the economy. First, changes in gas prices and the unemployment rate are reflected in changes in quantitative assessments over time. Second, the strong relationship between qualitative and quantitative economic assessments suggests responses to both are driven by common underlying factors. Third, and finally, consistent with the mecro-economic voting theory of Ansolabehere, Meredith and Snowberg (2011a), cross-sectional variation in reported unemployment rates reflects differences in respondents' probability of being unemployed.

\section{Survey Respondents Can Handle Numbers}

This section shows that survey respondents report perceptions of the price of gas that are quite accurate. Moreover, the more that respondents engage in activities that would increase their familiarity with the price of gas, such as driving, the more accurate their assessments

\footnotetext{
${ }^{12}$ For example, the percentage of people at the bottom, middle, and top tercile of the income distribution who have not heard of the unemployment rate is $38 \%, 21 \%$, and $11 \%$, respectively.
} 
are. This is contrary to research, discussed above, that is skeptical of respondents' abilities to report perceptions of any numerical quantity.

We focus on the price of gas, as gasoline is an important component of U.S. household consumption. ${ }^{13}$ Actual gas prices are also easy to observe, which facilitates comparison between respondents' assessments and actual prices. Moreover, previous work demonstrates that, in the aggregate, gas prices have an independent effect on presidential approval (Fox, 2009). Finally, the price of gas is one of the most frequently encountered numbers in a respondent's everyday environment.

We asked respondents the following question on the 2006 and 2008 American National Election Survey (ANES), and on the 2008 Cooperative Congressional Election Survey (CCES):

What is your best guess of the average price of a gallon of regular unleaded gasoline across all of [YOUR STATE] today?

Respondents accurately report the average price of gas in their state of residence. Figure 1 plots a histogram of the reported price of gas in each of the three surveys. We observe that the modal response in each survey tracks the actual average price of gas. It is particularly impressive that the large drop in gas prices between October and November 2008 is quickly reflected in survey responses.

Figure 2 plots the difference between respondents' reported price of gas and the actual average price of gas in the respondents' state in the month of the survey. This difference is distributed relatively evenly around a mean of about zero. On all three surveys, the average bias - the difference between the reported and actual price of gas - is slightly positive. The mean response overestimates the price of gas by approximately ten cents on all three surveys, while the median response overestimates the price by between six to ten cents.

Overall, the accuracy of assessments of gas prices show survey respondents are capable of accurately answering quantitative questions about a familiar quantity. The accuracy of

\footnotetext{
${ }^{13}$ Gasoline and motor oil account for about five percent of American household expenditures between 2007 and 2009. Consumption data for 2007 though 2009 is reported in U.S. Bureau of Labor Statistics news release USDL-10-1390.
} 
responses - the negative of the absolute difference between the reported and actual price of gas - is -20 to -30 cents across the three surveys, with the median deviation being slightly lower. ${ }^{14}$ Given that the average price of gas in the sample ranges from two to three dollars, this suggests a $10 \%$ to $15 \%$ average difference between the reported and actual price of gas.

The above analysis shows respondents are accurate, on average. However, there may be considerable heterogeneity in respondents' abilities to perceive and report numerical quantities. For example, more education may help respondents report more accurate numeric assessments. Table 1 explores this possibility by using a multi-variate regression to determine the correlates of bias and accuracy of reported gas prices in all three surveys.

The table shows that different types of people do not systematically differ in their ability to accurately answer questions about a familiar quantity. There are few covariates that are consistent predictors of either the bias or accuracy of assessments of the price of gas. Moreover, most of the coefficients are both small in magnitude and insignificant. There are two exceptions to this general pattern: Black and Hispanic respondents are significantly less accurate than non-Black, non-Hispanic respondents. Additionally, in contrast to findings in the next section about reported unemployment rates, there is little partisan difference in assessments of the price of gas.

Finally, although education is not significantly correlated with the accuracy of gas price assessments, other activities that increase a respondent's familiarity with a numerical quantity are. The 2006 ANES asked respondents both how many times a week they drove a car, and how often they noticed gas prices. Each additional day that a respondent reports driving makes them 0.8 cents $($ s.e. $=0.4)$ more accurate, while each additional time that a respondent reports noticing gas prices makes them 1.6 cents (s.e. $=0.4)$ more accurate (Ansolabehere, Meredith and Snowberg, 2011b). These point estimates suggest that everyday that a respondent drives and notices gas prices is associated with $12.5 \%$ improvement in his

\footnotetext{
${ }^{14}$ Note that as accuracy is defined as the negative of the absolute difference, accuracy increases as the absolute difference between a respondent's report and the actual price decreases. Gasoline price data is from the U.S. Department of Transportation.
} 
or her accuracy.

\section{Benchmarks Induce a Common Scale}

Heterogeneity in respondents' assessments of an economic quantity, such as the unemployment rate, is potentially quite useful for understanding the mechanisms underlying economic voting. Ideally, these assessments can produce a greater understanding of how differences in perceptions of the economic conditions measured by these quantities affect voter behavior. However, as outlined in Section 2.3, many respondents are unfamiliar with complicated quantities like the unemployment rate, or the scale on which those quantities are measured. Thus, heterogeneity in responses may be driven by misunderstandings of the definition of the unemployment rate, rather than actual heterogeneity in perceptions.

This section shows that careful question design reduces heterogeneity in reported unemployment rates, especially among low SES respondents. In particular, precisely defining the quantity of interest reduces the number of respondents that give very high responses, as we did in the following question from the 2006 and 2008 ANES, and the 2008 and 2009 CCES:

As far as you know, what is the current rate of unemployment? That is, of the adults in the US who wanted to work during the second week of October, what percent of them would you guess were unemployed and looking for a job?

Moreover, adding the following benchmarks (on the 2008 and 2009 CCES) to the above question about the unemployment rate significantly reduces the number of low SES respondents that give very high responses.

The unemployment rate in the U.S. has varied between $2.5 \%$ and $10.8 \%$ between 1948 and today. The average unemployment rate during that time was $5.8 \%$.

Yet, adding these benchmarks does not reduce meaningful variation in reported unemployment rates. 
We show these results in a randomized experiment with approximately 4,000 respondents, administered as part of the 2008 CCES. The experiment allows us to compare the responses of those who were exposed to the benchmarks, and those who were not. Three-quarters of these respondents were asked about the unemployment rate with a question that included the benchmarks, and the remaining one-quarter were asked the same question without them. We refer to these as the benchmarked and non-benchmarked samples, respectively. ${ }^{15}$

\subsection{A Simple Model of Survey Response}

The lack of familiarity with complicated economic quantities, like the unemployment rate, raises questions about whether or not assessments of these quantities are on a common scale. For example, respondents who are not familiar with the technical definition of the unemployment rate may report their perception of the percent of people out of work, rather than those that are out of work and looking for a job. That is, they may report their perception of the labor force non-participation rate, rather than their perception of the unemployment rate. ${ }^{16}$ Thus, heterogeneity in assessments of the unemployment rate may primarily reflect heterogeneity in definitions and scaling, rather than heterogeneity in perceptions of unemployment.

A well-designed question would substantially reduce heterogeneity in responses due to different understandings of the quantity of interest, without reducing meaningful variation. To ascertain whether including our benchmarks satisfy these goals requires a theory of what, exactly, constitutes meaningful variation, and which responses are due to lack of a common scale. Meaningful variation is easy to define: it is variation due to differences in perceptions of the economic concept underlying the quantity. As this cannot be measured directly, the rest of this section builds a simple model of survey response that makes predictions about

\footnotetext{
${ }^{15}$ Due to an error administrating the survey, the benchmarked sample allowed respondents to enter unemployment rates to the tenth of a percent, while the unframed sample was only able to enter them to the nearest percent. Truncating or rounding the responses in the benchmarked sample has almost no effect on the results presented here.

${ }^{16}$ Moreover, a large literature shows that individuals struggle to estimate low probabilities, like the probability that people are unemployed (Kahneman and Tversky, 1979; Snowberg and Wolfers, 2010).
} 
what would occur if a question's design reduces heterogeneity due to non-common scaling, while maintaining meaningful variation.

We assume there are three types of survey respondents: those who know the scale on which the unemployment rate is measured, those who do not know the scale, and those who are not attempting to correctly answer the question. Benchmarks would ideally provide a sense of scale to those who do not know it, without reducing the meaningful variation among those who do.

This simple structure is enough to deduce two patterns that we should observe if our question is well-designed. The first pattern is that more information about the definition and tendencies of the unemployment rate should reduce the proportion of respondents reporting very large unemployment rates (say, greater than 15\%). In particular, including the precise definition of the unemployment rate should produce an initial reduction, and the inclusion of benchmarks a further reduction.

Second, there should be a similar relationship between reported unemployment and qualitative economic evaluations among those who report an unemployment rate within the historical limits in both the benchmarked and non-benchmarked samples. Moreover, as only those who are not attempting to correctly answer the question provide responses greater than the historical maximum in the benchmarked sample, there should not be a significant relationship between reported unemployment rates and qualitative economic evaluations above the historical maximum.

To deduce a third pattern, we maintain an additional two hypotheses that refine the definition of what does - and does not - constitute meaningful variation. The argument in Section 2.3 suggests that low SES respondents will be particularly likely to have a different understanding of the scale on which unemployment is measured. Thus, we assume low SES respondents will be more likely to report a number closer to the labor-force non-participation rate. Maintaining this hypothesis, reductions in the amount of low SES respondents that report very high levels of unemployment should be interpreted as evidence that the benchmarks 
are reducing heterogeneity due to different understandings of the unemployment rate.

We further maintain that meaningful variation follows the mecro-economic voting hypothesis of Ansolabehere, Meredith and Snowberg (2011a). Under this hypothesis, individuals gather local economic information to inform them about their future risks of unemployment. Thus, those who face a greater risk of unemployment should perceive the unemployment rate to be higher.

Taking these two maintained hypotheses together, we deduce a third pattern that should be observed if our benchmarks are well-designed: there should be substantial heterogeneity in the non-benchmarked sample, with those at a greater risk of unemployment and those with low SES providing answers that are, on average, much higher. The benchmarked sample should provide responses consistent with their relative risk of unemployment, but the differences between high and low SES respondents should be substantially reduced.

The next three subsections evaluate the extent to which the above patterns are observed in data from a randomized experiment implemented as part of the 2008 CCES.

\subsection{Reduction of Very High Responses}

As indicated above, our first step is to precisely define the unemployment rate. The addition of the definition of unemployment has some effect: only $30 \%$ of respondents report unemployment rates above the historical high of $10.8 \%$, compared with $50 \%$ in previous studies by Conover, Feldman and Knight (1986) and Holbrook and Garand (1996). However, very high responses are still concentrated among low SES respondents. ${ }^{17}$

The top panel of Figure 3 suggests that a substantial proportion of the population is roughly aware that $6.5 \%$ was the true unemployment rate in October 2008, with just under one-half of the sample reporting unemployment rates of between six and seven percent.

\footnotetext{
${ }^{17}$ We do not provide an opt-out prompt when asking these question, and request that respondents report a number if they try to skip the question. Respondents can opt-out by attempting to skip the question a second time. Our resulting response rates are $99 \%$ in the benchmarked and $98 \%$ in the non-benchmarked samples, respectively. This protocol is consistent with Curtin's (2007) finding that providing an opt-out significantly reduced responses, without significantly increasing the accuracy of responses.
} 
However, another one-third of the responses are higher than 10.8\%, the highest unemployment rate since the Bureau of Labor Statistics unemployment series began in 1948. This implies either that there are many respondents who believe the unemployment rate is at least twice as high as it actually is, or that many of the extreme answers come from a poor understanding the scale of the unemployment rate.

Next, we add benchmarks to the question. The goal of the benchmarks is to reduce the difference between respondents' perceptions of the quantity of interest and their reported perceptions of the quantity. This divergence is often described as measurement error (Ansolabehere, Rodden and Snyder, 2008). However, researchers must be careful to construct benchmarks that minimize the effect on a respondent's ability or desire to express their true perception of the quantity. Failure to do so may increase, rather than decrease, measurement error.

The benchmarks we construct provide the respondent with a sense of the smallest and largest feasible unemployment rates by telling them the historical highs and lows of unemployment during the previous sixty years. It also gives guidance on the average level of unemployment across time.

As shown in the middle panel of Figure 3, providing respondents with benchmarks substantially reduces, but does not eliminate, the heterogeneity in assessments of the unemploy-

ment rate. Just as in the non-benchmarked sample, slightly fewer than $50 \%$ of respondents report unemployment rates of 6-7\%. However, the percentage of answers above the largest historical unemployment rate is reduced from over $30 \%$ to about $15 \%$ of the sample. Thus, the first pattern conjectured above holds: more information about the definition and tendencies of the unemployment rate reduces the proportion of respondents reporting very large unemployment rates.

\subsection{Comparison with Qualitative Evaluations}


If respondents view higher unemployment as a sign the economy is getting worse, then there should be a relationship between perceptions of unemployment and qualitative economic evaluations, like the standard retrospective question discussed in the introduction. That is, if reported unemployment rates are capturing variation in unemployment perceptions, we expect that respondents who report higher unemployment rates will report more negative evaluations of the aggregate economy. ${ }^{18}$

This subsection examines how including benchmarks affects the estimated relationship between the reported unemployment rate and retrospective economic evaluations. As noted above, if our simple model of survey response is correct, and the benchmarks are welldesigned, then there should be a similar relationship between reported unemployment and qualitative economic evaluations among those who report an unemployment rate within the historical limits in both the benchmarked and non-benchmarked samples. Moreover, there should be no relationship between reported unemployment rates and qualitative economic evaluations above the historical maximum in the benchmarked sample.

These predicted patterns are consistent with the data shown in Figure 4. In particular, the top panels show the (Loess smoothed) relationship between respondents' reported unemployment perceptions and their qualitative assessment of business conditions and the employment situation, elicited by asking:

How would you rate the present general business conditions in your area? Good, normal or bad?

What would you say about available jobs in your area right now? There are plenty of available jobs in my area, there are not so many available jobs in my area, or jobs in my area are hard to get? ${ }^{19}$

\footnotetext{
${ }^{18}$ Of course, unemployment perceptions and the threshold at which a respondent will say the economy has gotten worse are not necessarily independent. The answers to these questions could be uncorrelated or anti-correlated if respondents who have a higher threshold also systematically perceive higher levels of unemployment. We view this as an unlikely possibility, and one that is contradicted by the data in the next section.

${ }^{19}$ These are the standard current business conditions and employment questions from the Conference Board survey.
} 
We code the extremes of "good" and "plenty of jobs" as 1, and "bad" and "hard to get" as 3. All data comes from the 2008 CCES. $^{20}$ The bottom two panels show the relationship between respondents' reported unemployment perceptions and their retrospective economic evaluation, and vote choice, respectively.

All four panels are plotted on a log scale to focus on the variation within the historical boundaries. For all four qualitative assessments, the relationship between unemployment perceptions and qualitative assessments within that range is quite similar in the benchmarked and non-benchmarked sample. Statistical tests, contained in the appendix, confirm this appearance. Moreover, in all four panels, there appears to be no relationship between unemployment perceptions and qualitative assessments above the historical maximum in the benchmarked sample. ${ }^{21}$ Once again, statistical tests contained in the appendix confirm this appearance.

Thus, the second pattern conjectured above holds: including benchmarks does not affect the relationship between unemployment perceptions and qualitative assessments in the range defined by historical limits. Moreover, there is no relationship between unemployment perceptions and qualitative assessments above the historical maximum.

\subsection{Mecro-patterns of Unemployment Perceptions}

Finally, we examine how introducing the benchmark changes differences in perceptions of unemployment between groups. We show that although including benchmarks reduces the heterogeneity between groups, it does not affect the overall pattern of responses: namely, respondents in groups with a higher risk of unemployment report higher average percep-

\footnotetext{
${ }^{20}$ While it would be interesting to compare quantitative and qualitative employment questions in 2009 as well, in that year, $90 \%$ of respondents reported jobs were "hard to get". This shows one of the benefits of using quantitative questions: the fact that responses are open means that they measure variation even in extreme circumstances.

${ }^{21}$ One additional result of note is that no relationship between unemployment perceptions and qualitative assessments above the historical maximum in the non-benchmarked sample either. Our model implies that responses above the historical maxmium in the non-benchmarked sample come from a combination of people who don't know the scale on which unemployment is measured and people who are not attempting to answer the question. This pattern thus suggests that those who do not know the scale on which the unemployment rate is measured do not share a common misunderstanding of the scale.
} 
tions of the unemployment rate. These patterns are thus consistent with the third set of patterns deduced in Section 4.1, and hence, with the question being well-designed under our maintained hypothesis. Moreover, these patterns are substantially different from patterns found in qualitative evaluations, leading to the conclusion that quantitative questions capture additional, meaningful variation.

Data from the benchmarked and non-benchmarked sample is examined in Table 2 . Columns 1 and 2 present coefficients from least absolute deviation (LAD) regressions of the reported unemployment rate, in the benchmarked and non-benchmarked sample respectively, on a host of covariates. LAD regressions, sometimes referred to as median regressions, minimize the impact of outliers on estimated coefficients. The coefficients in these regressions report how the median value of reported unemployment associates with a one-unit change in the independent variable, holding all else equal. For example, the median respondent making under $\$ 20,000$ dollars a year reports unemployment rates that are 0.74 percentage points (s.e. $=0.21$ ) higher in the benchmarked sample, as compared to 13.4 percentage points $($ s.e. $=5.6)$ higher in the non-benchmarked sample. This is consistent with the general pattern: the same variables significantly relate to unemployment assessments in both the benchmarked and non-benchmarked sample. However, the magnitudes are sometimes dramatically different.

Adding benchmarks generally reduces differences between groups in their assessments of unemployment. To perform the comparison, we must first recode each respondents' unemployment assessment as the percentile of the distribution that his or her unemployment assessment falls, within his or her sample. This is necessary because, if our theory is correct, respondents in the two samples are implicitly using different scales. Thus, in this coding, 100 means that a respondent had the highest report in his or her sample, and 0 the lowest.

Columns 3 and 4 examine how changes in the percentile of respondents' reports (within their sample) are correlated with the same covariates as before. For example, in the nonbenchmarked sample, holding all else equal, the average respondent making under $\$ 20,000$ 
dollars a year reports a 19.3 percentile $($ s.e. $=5.8)$ higher unemployment rate than the average respondent making more than $\$ 120,000$ dollars a year. In comparison, this shrinks to 10.7 percentiles $($ s.e. $=2.3$ ) higher in the benchmarked sample. Column 5 reports difference between these estimates is 8.6 percentiles $($ s.e. $=6.2$ ), although this difference is not statistically significant. Including benchmarks causes statistically significant reductions in the difference in reports between those who never attended college and those with a Bachelor's degree, as well as those with low and high incomes. In addition, we estimate a statistically significant reduction in the difference between married women and unmarried men, who are the least and most likely gender-marriage combinations, respectively, to participate in the labor force. As we conjecture that those with less education, lower incomes, and those outside the labor force are less likely to be aware of the scale on which the unemployment rate is measured, this suggests that our benchmarks help put individuals on a common scale. ${ }^{22}$

A final question of interest here is whether we could have observed the same mecroeconomic patterns using only qualitative assessments. To determine this, in Table 3 we regress the same three qualitative assessments used in Figure 4 on the same set of demographic controls in Table 2. The results are striking: the only mecro-economic pattern in Table 3 is found in different income groups' qualitative evaluation of the employment situation. $^{23}$ This shows that quantitative questions are able to capture additional meaningful variation that is difficult to observe in qualitative evaluations.

The only variables that consistently correlate with all three qualitative economic evaluations examined in Table 3 are partisan indicators. The next section uses both quantitative and qualitative questions to understand the sources of this partisan bias.

Thus, all three sets of patterns deduced above are consistent with the data. While this

\footnotetext{
${ }^{22}$ There are concerns about the reliability of internet surveys such as the CCES (see Malhotra and Krosnick, 2007 and Yeager et al., 2009, or Stephenson and Crête, 2011 for an opposing view). To alleviate such concerns, we replicate the regressions in Table 2 on responses to a reported unemployment rate question on the 2006 and 2008 ANES in the Appendix. On both surveys, the question did not contain any benchmarks, and the 2006 question differed slightly as it asked respondents their perceptions of the unemployment rate in their state of residence. It is reassuring that the results reported in Table A.2 show very similar patterns in the ANES data to those observed in the CCES data.

${ }^{23}$ Conducting the analyses in Table 3 using an ordered probit produces qualitatively similar results.
} 
implies that our question is well-designed under the maintained hypotheses, it, by no means, can prove that it is well-designed. Our maintained hypothesis could be wrong, or there may be other implications contradicted by the data.

\section{$5 \quad$ Understanding Partisan Bias}

In this section we show how combining quantitative and qualitative questions can reveal more information than either type of question alone. In particular, we seek a better understanding of the partisan differences in unemployment perceptions reported in the previous section. ${ }^{24}$ We find evidence that partisanship either affects the reporting of both perceptions and evaluations, or affects economic judgments in a particularly odd way: opponent partisans would have to be more lenient on the incumbent to rationalize the observed patterns.

Consistent with previous results, Table 4 shows that supporters of the incumbent party (Republicans in 2008), report more positive assessments of employment in both quantitative and qualitative questions. However, Table 4 indicates that the qualitative reports are more related to partisan identification than the quantitative reports. In particular, nearly an identical number of respondents report that the unemployment rate is below $5.6 \%$ as report a positive evaluation of the employment situation. Yet, five times as many Republicans as Democrats report a positive qualitative evaluation of the employment situation (28.1\% vs. 5.8\%) compared with two and a half times as many Republicans as Democrats reporting an unemployment rate under $5.6 \%$ (24.7\% vs. $10.2 \%)$.

The literature has identified three potential sources of partisan differences in responses to qualitative economic questions. First, perceptions of the economy may relate with partisan affiliations. This could occur either because partisanship directly affects economic perceptions (Gerber and Huber, 2010), or because partisanship is related to unmeasured determinants of economic perceptions, like personal experience with economy (Ansolabehere,

\footnotetext{
${ }^{24}$ The finding that there are partisan differences in unemployment assessments is consistent with a large literature showing that partisan attachments affect economic evaluations (Wlezien, Franklin and Twiggs, 1997; Anderson, Mendes and Tverdova, 2004; Evans and Andersen, 2006; Evans and Pickup, 2010).
} 
Meredith and Snowberg, 2011a). Second, partisan affiliation may affect respondents' reports conditional on perceptions. Specifically, "partisan cheerleading" may cause supporters of the incumbent political party to report economic assessments that are more favorable than their actual economic perceptions. Third, and finally, partisanship may affect the criterion used to judge the economy. For example, a Democrat may judge that a $2 \%$ growth rate is "acceptable" when a Democrat is in power, but "unacceptable" when a Republican is in power. It is difficult to separate these three sources of partisan difference in cross-sectional data, as all three have the same effect: supporters of the incumbent report more positive evaluations of economic performance than opponents. ${ }^{25}$

Quantitative questions provide additional leverage for identifying the sources of partisan differences in economic assessments. Because quantitative assessments do not involve judgment, the partisan differences in reported unemployment rates observed in Section 4 must result either from differences in perceptions or in reporting.

Further evidence about the source of partisan bias in quantitative questions is gained by comparing the correlates of reported unemployment rates on the 2008 and 2009 CCES. Over this time period Barack Obama (a Democrat) replaced George W. Bush (a Republican) in the White House. In contrast to 2008, Table A.1 in the Appendix shows that, in 2009, Republicans reported slightly higher rates of unemployment than Democrats. Moreover, other patterns of response remained largely the same as in $2008 .{ }^{26}$ This suggests that differential economic experiences cannot be the only explanation for the partisan differences we observe in reported unemployment rates in Table 4 .

Moreover, quantitative assessments can also be used to indirectly test for partisan differences in criteria used to judge the employment situation. To see this, consider a model where respondents randomly draw perceptions of the unemployment rate from a distribu-

\footnotetext{
${ }^{25}$ Previous research uses experimental or quasi-experimental variation in survey design to isolate survey effects (Wilcox and Wlezien, 1993; Palmer and Duch, 2001; Sturgis, Choo and Smith, 2009), or eschews survey data altogether and considers consumption data (Gerber and Huber, 2009). Unfortunately, these techniques do not separate whether partisanship affects perceptions or judgements of economic conditions.

${ }^{26}$ As shown in Table A.1, differences in perceptions between age groups were attenuated in 2009, while differences in perceptions between race / ethnicity and education groups were enhanced.
} 
tion that may vary by political party, and judge that perception according to whether it is higher or lower than a threshold. Respondents who perceive that the unemployment rate is below their evaluative threshold report a positive evaluation of unemployment, otherwise they report a negative evaluation. If supporters of the incumbent party apply a less stringent threshold when evaluating the economy, then supporters who report a positive evaluation will have a higher perception of the unemployment rate than opponents who report a positive evaluation. To put this another way: among those reporting a positive qualitative economic evaluation, the highest reported unemployment rates should come from members of the incumbent party. Likewise, among those reporting a negative qualitative economic evaluation, the lowest reported unemployment rates should come from members of the opposition party.

We do not find evidence consistent with criteria used to judge the employment situation being affected by partisanship. In contrast, Table 5 shows that in the 2008 CCES, Democrats generally report higher unemployment rates than Republicans, conditional on their qualitative assessments of unemployment. ${ }^{27}$ For example, the interquartile range of reported unemployment rates among Republicans with a neutral qualitative evaluation is $5.8 \%$ to $7.0 \%$. In comparison, the interquartile range of Independents and Democrats with a neutral qualitative evaluation is $6.0 \%$ to $7.5 \%$ and $6.0 \%$ to $8.5 \%$, respectively. Thus, if partisans are using different criteria to judge the employment situation, it would have to be the case that Republicans are using a stricter criteria than Democrats. As this is counter to theory, we conclude that partisan differences mainly enter in reporting of economic assessments (whether elicited using qualitative or quantitative questions). Moreover, as the distribution of unemployment reports by party are less skewed than qualitative unemployment assessments, we conclude that these differences are less pronounced in quantitative questions.

\footnotetext{
${ }^{27}$ We cannot perform a similar analysis in 2009 because roughly $90 \%$ of the sample reports negative evaluations of the employment situation, see Footnote 20.
} 


\section{Conclusion}

Many theories in political science, such as theories of economic voting, are fundamentally rooted in numbers. In particular, the focus in the economic voting literature is on how vote shares change with changes in economic quantities such as GDP, inflation, or the unemployment rate. While survey questions that ask about numbers would form a tighter link between theory and survey data, numerous concerns have limited their use.

We have shown that survey respondents can handle quantitative questions, especially about familiar quantities such as the price of gas. Moreover, respondents' accuracy is affected by little else other than the regularity with which they are exposed to information about the price of gas. This finding stands in contrast to recent public opinion work demonstrating the inaccuracy of responses, particularly among certain types of individuals, to open-ended questions about quantities. ${ }^{28}$

Asking questions about more complex and unfamiliar quantities is a greater challenge. However, we are confident that these challenges can be overcome in many situations through careful question design. In particular, we show that providing information about the historical tendencies of a quantity can be quite useful in giving respondents a sense of the scale of the quantity in question, without obscuring meaningful variation in responses.

Quantities are important to voters' evaluations of many policies. In particular, budget and trade deficits, the cost of social programs, the number of people affected by a policy, and the number of war dead are all naturally expressed as numbers. The results here suggest that many of the barriers to using quantitative questions are surmountable, and provides some guidance on how they may be overcome.

That said, the value of quantitative questions goes beyond the ability to reduce measurement error or discover new, interesting patterns in the data. Many political economy

\footnotetext{
${ }^{28}$ For a few examples see Conover, Feldman and Knight (1986); Nadeau, Niemi and Levine (1993); Holbrook and Garand (1996); Kuklinski et al. (2000); Gilens (2001); Sigelman and Niemi (2001); Kaplowitz, Fisher and Broman (2003); Ansolabehere, Snowberg and Snyder (2005); Martinez, Wald and Craig (2008) and Herda (2010).
} 
theories are about specific quantities - GDP growth, levels of employment, tax policy, or changes in prices (inflation) - they are not about "feelings about the economy". Qualitative survey questions seem to conflate the underlying variables of interest-perceptions of economic quantities - with outcomes - evaluations of those perceptions and resulting political behavior. Thus, qualitative questions make, at best, an indirect statement about consumers' or voters' utilities. Those statements are not irrelevant, but it has long been known that direct comparisons of utilities are difficult. And, more importantly, they are not the primitives of theoretical models. 


\section{References}

Alesina, Alberto, John Londregan and Howard Rosenthal. 1993. "A Model of the Political Economy of the United States." American Political Science Review 87(1):12-33.

Anderson, Christopher J., Silvia M. Mendes and Yuliya V. Tverdova. 2004. "Endogenous Economic Voting: Evidence from the 1997 British Election." Electoral Studies 23(4):683708.

Ansolabehere, Stephen, Erik Snowberg and James M. Snyder. 2005. "Unrepresentative Information The Case of Newspaper Reporting on Campaign Finance." Public Opinion Quarterly 69(2):213-231.

Ansolabehere, Stephen, Jonathan Rodden and James M. Snyder. 2008. "The Strength of Issues: Using Multiple Measures to Gauge Preference Stability, Ideological Constraint, and Issue Voting." American Political Science Review 102(2):215-232.

Ansolabehere, Stephen, Marc Meredith and Erik Snowberg. 2011a. "Mecro-Economic Voting: Local Information and Micro-Perceptions of the Macro-Economy." Presented at the annual meeting of the Midwest Political Science Association. The Palmer House Hilton, Chicago.

Ansolabehere, Stephen, Marc Meredith and Erik Snowberg. 2011b. Sociotropic Voting and the Media. In Improving Public Opinion Surveys: Interdisciplinary Innovation and the American National Election Survey, ed. John H. Aldrich and Kathleen McGraw. Princeton University Press.

Bartels, Larry M. 2002. "Beyond the Running Tally: Partisan Bias in Political Perceptions." Political Behavior 24(2):117-150.

Beyth-Marom, Ruth. 1982. "How Probable is Probable? A Numerical Translation of Verbal Probability Expressions." Journal of Forecasting 1(3):257-269.

Blendon, Robert J., John M. Benson, Mollyann Brodie, Richard Morin, Drew E. Altman, Daniel Gitterman, Mario Brossard and Matt James. 1997. "Bridging the Gap Between the Public's and Economists' Views of the Economy." The Journal of Economic Perspectives 11(3):105-118.

Bruine de Bruin, Wandi, Baruch Fischhoff, Susan G. Millstein and Bonnie L. HalpernFelsher. 2000. "Verbal and Numerical Expressions of Probability: It is a Fifty-Fifty Change." Organizational Behavior and Human Decision Processes 81(1):115-131.

Bullock, John G., Alan S. Gerber and Gregory A. Huber. 2010. "Partisan Bias in Factual Beliefs about Politics." Yale University, mimeo.

Cleveland, William S., Susan J. Devlin and Eric Grosse. 1988. "Regression by Local Fitting: Methods, Properties, and Computational Algorithms." Journal of Econometrics 37(1):87114. 
Conover, Pamela Johnstone, Stanley Feldman and Kathleen Knight. 1986. "Judging Inflation and Unemployment: The Origins of Retrospective Evaluations." The Journal of Politics 48(3):565-588.

Curtin, Richard. 2007. "What U.S. Consumers Know About Economic Conditions." University of Michigan, memeo.

Erev, Ido and Brent L. Cohen. 1990. "Verbal versus Numerical Probabilities: Efficiency, Biases, and the Preference Paradox." Organization Behavior and Human Decision Processes 45(1):1-18.

Erikson, Robert S., Michael B. MacKuen and James A. Stimson. 2002. The Macro Polity. Cambridge, UK: Cambridge University Press.

Evans, Geoffrey and Mark Pickup. 2010. "Reversing the Causal Arrow: The Political Conditioning of Economic Perceptions in the 2000-2004 U.S. Presidential Election Cycle." The Journal of Politics 72(4):1236-1251.

Evans, Geoffrey and Robert Andersen. 2006. "The Political Conditioning of Economic Perceptions." The Journal of Politics 68(1):194-207.

Fair, Ray C. 1978. "The Effect of Economic Events on Votes for President." The Review of Economics and Statistics 60(2):159-173.

Fox, Gerald T. 2009. "Partisan Divide on War and the Economy: Presidential Approval of G. W. Bush." Journal of Conflict Resolution 53(6):905-933.

Gerber, Alan S. and Gregory K. Huber. 2009. "Partisanship and Economic Behavior: Do Partisan Differences in Economic Forecasts Predict Real Economic Behavior?" American Political Science Review 103(3):407-426.

Gerber, Alan S. and Gregory K. Huber. 2010. "Partisanship, Political Control, and Economic Assessments." American Journal of Political Science 54(1):153-73.

Gilens, Martin. 2001. "Political Ignorance and Collective Policy Preferences." American Political Science Review 95(2):379-395.

Groves, Robert M., Floyd J. Fowler Jr., Mick P. Couper, James M. Lepkowski, Eleanor Singer and Roger Tourangeau. 2004. Survey Methodology. Hoboken, NJ: Wiley.

Herda, Daniel. 2010. "How Many Immigrants? Foreign-Born Population Innumeracy in Europe." Public Opinion Quarterly, 74(4):674-695.

Hetherington, Marc J. 1996. "The Media's Role in Forming Voters' National Economic Evaluations in 1992." American Journal of Political Science 40(2):372-395.

Holbrook, Thomas and James C. Garand. 1996. "Homo Economus? Economic Information and Economic Voting." Political Research Quarterly 49(2):351-375. 
Imbens, Guido W. and Thomas Lemieux. 2008. "Regression discontinuity designs: A guide to practice." Journal of Econometrics 142(2):615-635.

Juster, F. Thomas. 1966. "Consumer Buying Intentions and Purchase Probability: An Experiment in Survey Design." Journal of the American Statistical Association 61(315):658696.

Kahneman, Daniel and Amos Tversky. 1979. "Prospect Theory: An Analysis of Decision under Risk." Econometrica 47(2):263-292.

Kaplowitz, Stan A., Bradley J. Fisher and Clifford L. Broman. 2003. "How Accurate Are Perceptions of Social Statistics about Blacks and Whites? Effects of Race and Education." Public Opinion Quarterly 67(2):237-243.

Kinder, Donald R. and D. Roderick Kiewiet. 1979. "Economic Discontent and Political Behavior: The Role of Personal Grievances and Collective Economic Judgments in Congressional Voting." American Journal of Political Science 23(3):495-527.

Kinder, Donald R. and D. Roderick Kiewiet. 1981. "Sociotropic Politics: The American Case." British Journal of Political Science 11(2):129-161.

Kramer, Gerald H. 1971. "Short-Term Fluctuations in US Voting Behavior, 1896-1964." The American Political Science Review 65(1):131-143.

Kramer, Gerald H. 1983. "The Ecological Fallacy Revisited: Aggregate-versus Individuallevel Findings on Economics and Elections, and Sociotropic Voting." The American Political Science Review 77(1):92-111.

Krosnick, Jon A. 1991. "Response Strategies for Coping with the Cognitive Demands of Attitude Measures in Surveys." Applied Cognitive Psychology 5(3):213-236.

Kuklinski, James H., Paul J. Quirk, Jennifer Jerit and Robert F. Rich David Schwieder. 2000. "Misinformation and the Currency of Democratic Citizenship." Journal of Politics $62(3): 790-816$.

MacKuen, Michael B., Robert S. Erikson and James A. Stimson. 1992. "Peasants or Bankers? The American Electorate and the US Economy." The American Political Science Review 86(3):597-611.

Malhotra, Neil and Jon A. Krosnick. 2007. "The Effect of Survey Mode and Sampling on Inferences about Political Attitudes and Behavior: Comparing the 2000 and 2004 ANES to Internet Surveys with Nonprobability Samples." Political Analysis 15(3):286-323.

Manski, Charles F. 2004. "Measuring Expectations." Econometrica 72(5):1329-1376.

Martinez, Michael D., Kenneth D. Wald and Stephen C. Craig. 2008. "Homophobic Innumeracy? Estimating the Size of the Gay and Lesbian Population." Public Opinion Quarterly $72(4): 753-767$. 
Moxey, Linda M. and Anthony J Sanford. 2000. "Communicating Quantities: A Review of Psycholinguistic Evidence of How Expressions Determine Perspectives." Applied Cognitive Psychology 14(3):237-255.

Nadeau, Richard and Richard G Niemi. 1995. "Educated Guesses: The Process of Answering Factual Knowledge Questions in Surveys." Public Opinion Quarterly 59(3):323-346.

Nadeau, Richard, Richard G. Niemi and Jeffrey Levine. 1993. "Innumeracy About Minority Populations." Public Opinion Quarterly 57(3):332-347.

Palmer, Harvey D. and Raymond M. Duch. 2001. "Do Surveys Provide Representative or Whimsical Assessments of the Economy?" Political Analysis 9(1):58-77.

Rockwood, Todd H., Roberta L. Sangster and Don A. Dillman. 1997. "The Effect of Response Categories on Questionnaire Answers: Context and Mode Effects." Sociological Methods \& Research 26(1):118-140.

Schuman, Howard and Stanley Presser. 1981. Questions and Answers in Attitude Surveys. New York: Academic Press.

Schwarz, Norbert, Hans-J. Hippler, Brigitte Deutsch and Fritz Strack. 1985. "Response Scales: Effects of Category Range on Reported Behavior and Comparative Judgments." Public Opinion Quarterly 49(3):388-395.

Sigelman, Lee and Richard G. Niemi. 2001. "Innumeracy about Minority Populations: African Americans and Whites Compared." Public Opinion Quarterly 65(1):86-94.

Snowberg, Erik and Justin Wolfers. 2010. "Explaining the Favorite-Longshot Bias: Is it Risk-Love or Misperceptions?" Journal of Political Economy 118(4):723-746.

Stephenson, Laura B. and Jean Crête. 2011. "Studying Political Behavior: A Comparison of Internet and Telephone Surveys." International Journal of Public Opinion Research $23(1): 24-55$.

Sturgis, Patrick, Martin Choo and Patten Smith. 2009. "Response Order, Party Choice, and Evaluations of the National Economy: A Survey Experiment." Survey Research Methods $3(1): 7-12$.

Tourangeau, Roger, Kenneth Rasinski, Jared B. Jobe, Tom W. Smith and William F. Pratt. 1997. "Sources of Error in a Survey on Sexual Behavior." Journal of Official Statistics $13(4): 341-365$.

Tourangeau, Roger and Tom W. Smith. 1996. "Asking Sensitive Questions: The Impact of Data Collection Mode, Question Format, and Question Context." Public Opinion Quarterly 60(2):275-304.

van der Brug, Wouter, Cees van der Eijk and Mark Franklin. 2007. The Economy and the Vote: Economic Conditions and Elections in Fifteen Countries. Cambridge University Press. 
Wallsten, Thomas S. 1986. "Measuring the Vague Meanings of Probability Terms." Journal of Experimental Psychology: General 115(4):348-365.

Wallsten, Thomas S., David V. Budescu, Rami Zwick and Steven M. Kemp. 1993. "Preference and Reasons for Communicating Probabilistic Information in Numerical or Verbal Terms." Bulletin of the Psychonomic Society 31:135-138.

Wilcox, Nathaniel and Christopher Wlezien. 1993. "The Contamination of Responses to Survey Items: Economic Perceptions and Political Judgments." Political Analysis 5(1):181213.

Wlezien, Christopher, Mark Franklin and Daniel Twiggs. 1997. "Economic Perceptions and Vote Choice: Disentangling the Endogeneity." Political Behavior 19(1):7-17.

Wright, Daniel B., George D. Gaskell and Colm A. O’Muircheartaigh. 1994. "How Much is Quite a Bit? Mapping Between Numerical Values and Vague Quantifiers." Applied Cognitive Psychology 8:479-496.

Yeager, David S., Jon A. Krosnick, LinChiat Chang, Harold S. Javitz, Matthew S. Levindusky, Alberto Simpser and Rui Wang. 2009. "Comparing the Accuracy of RDD Telephone Surveys and Internet Surveys Conducted with Probability and Non-Probability Samples." Stanford University, mimeo.

Zaller, John and Stanley Feldman. 1992. "A Simple Theory of the Survey Response: Answering Questions versus Revealing Preferences." American Journal of Political Science 36(3):579-616. 
Figure 1: Distribution of Reports of Average State Gas Price
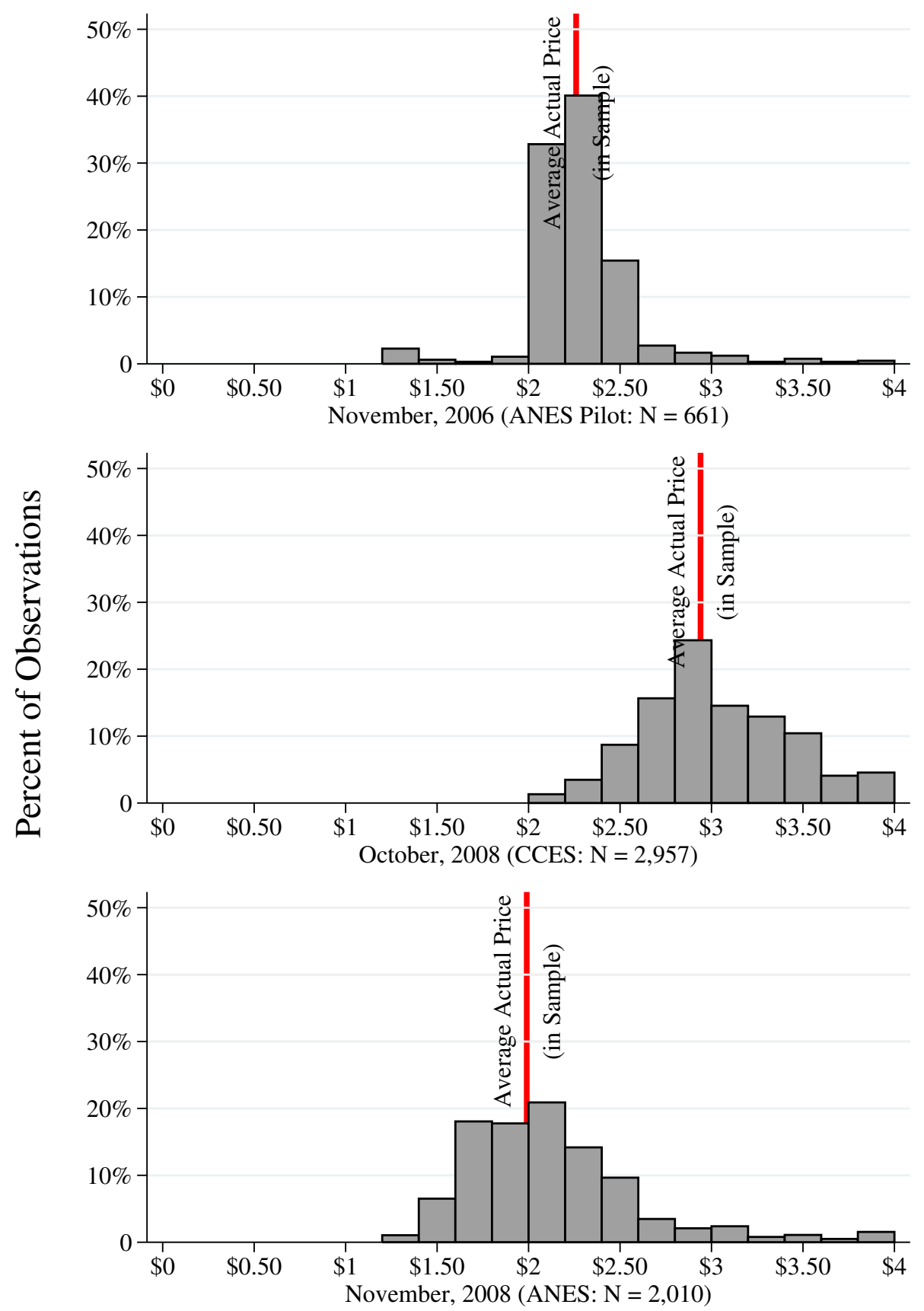

Notes: Top and bottom $1 \%$ of responses are set to the ninety-ninth and first percentile answer, respectively. 
Figure 2: Distribution of Bias in Reports of Average State Gas Price
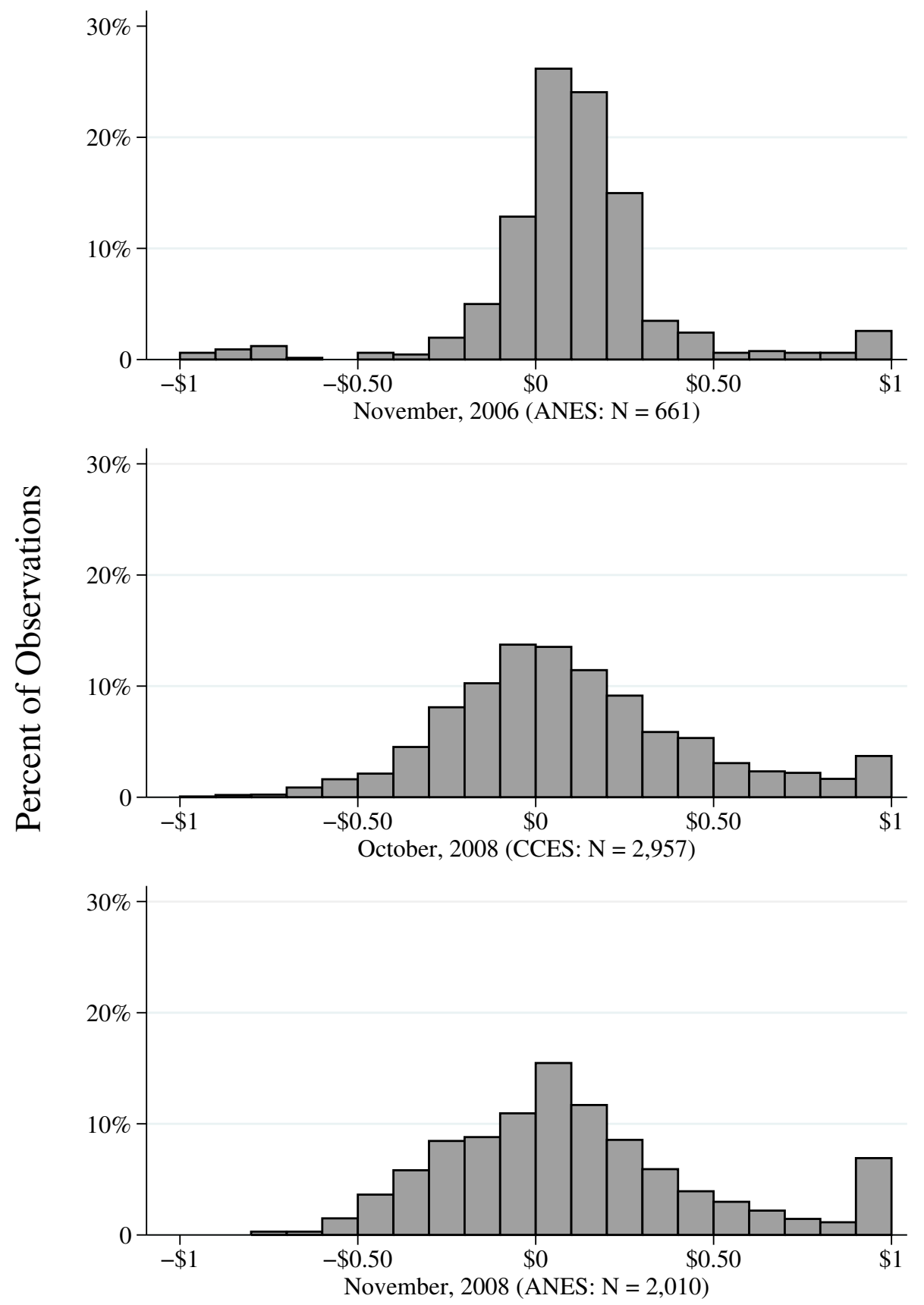

Notes: Errors are trimmed to be between $-\$ 1$ and $\$ 1$.

Figures and Tables-2 


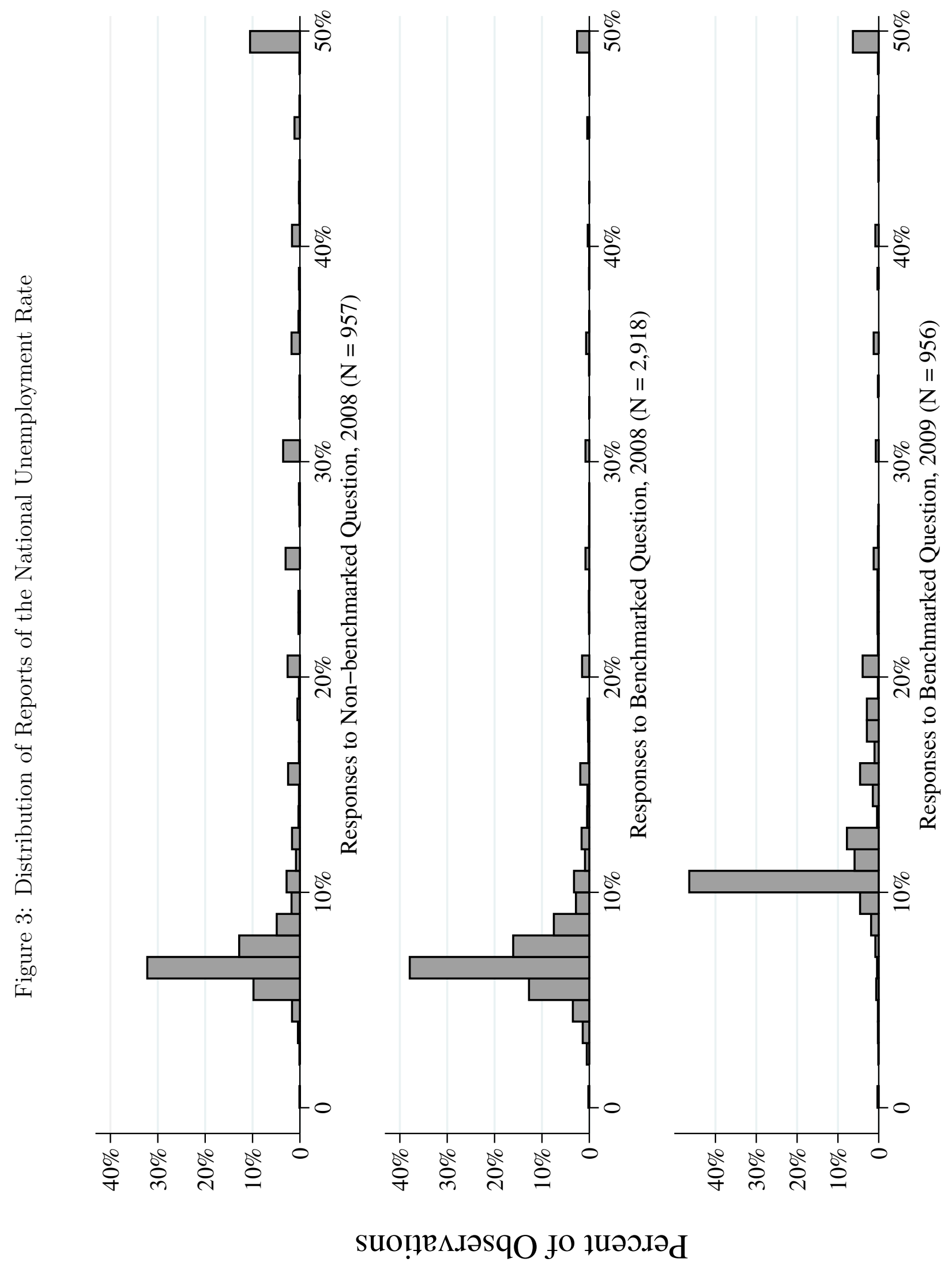

Figures and Tables-3 
Figure 4: Relationship Between Qualitative and Quantitative Evaluations

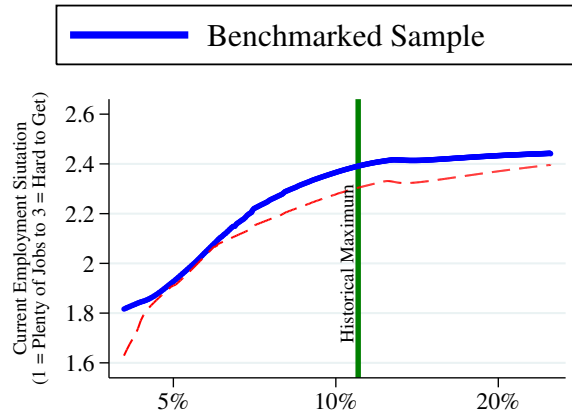
- - - - - Non-benchmarked Sample
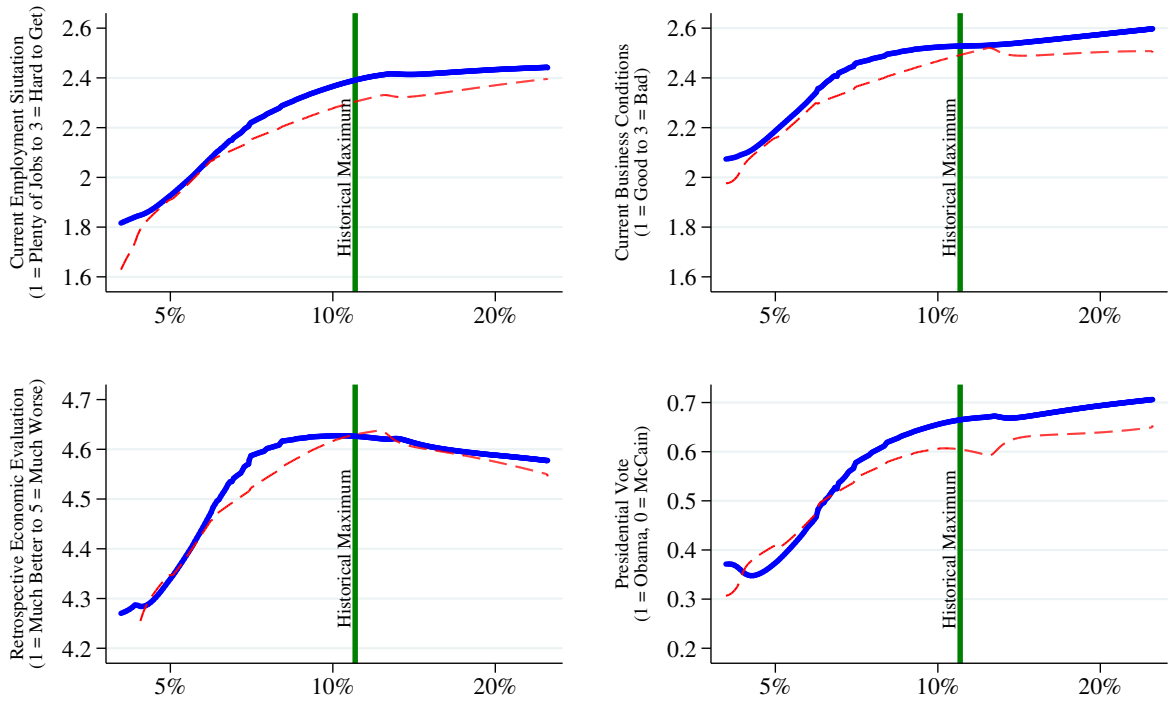

Reported Unemployment Rate (Log Scale)

Notes: Each figure is Loess smoothed using a bandwidth of 0.8 (Cleveland, Devlin and Grosse, 1988). 
Table 1: Correlates of Reported Average Gas Price

\begin{tabular}{|c|c|c|c|c|c|c|}
\hline \multirow[b]{2}{*}{ Dependent Variable } & \multicolumn{2}{|c|}{$2006 \operatorname{ANES}(\mathrm{N}=661)$} & \multicolumn{2}{|c|}{$2008 \operatorname{CCES}(\mathrm{N}=2,957)$} & \multicolumn{2}{|c|}{$2008 \operatorname{ANES}(\mathrm{N}=2,010)$} \\
\hline & Bias & Accuracy & Bias & Accuracy & Bias & Accuracy \\
\hline Mean Value & 0.101 & -0.193 & 0.102 & -0.273 & 0.118 & -0.292 \\
\hline Median Value & 0.101 & -0.131 & 0.057 & -0.202 & 0.080 & -0.215 \\
\hline Democrat & $\begin{array}{l}-0.024 \\
(0.027)\end{array}$ & $\begin{array}{l}-0.008 \\
(0.021)\end{array}$ & $\begin{array}{c}0.067^{* * *} \\
(0.017)\end{array}$ & $\begin{array}{c}-0.036^{* * *} \\
(0.012)\end{array}$ & $\begin{array}{c}0.014 \\
(0.025)\end{array}$ & $\begin{array}{c}0.011 \\
(0.018)\end{array}$ \\
\hline Independent & $\begin{array}{l}-0.020 \\
(0.029)\end{array}$ & $\begin{array}{c}0.010 \\
(0.022)\end{array}$ & $\begin{array}{c}0.063^{* * *} \\
(0.017)\end{array}$ & $\begin{array}{c}-0.036^{* * *} \\
(0.012)\end{array}$ & $\begin{array}{c}0.028 \\
(0.025)\end{array}$ & $\begin{array}{l}-0.013 \\
(0.017)\end{array}$ \\
\hline Age $18-44$ & $\begin{array}{l}0.042 \\
(0.031)\end{array}$ & $\begin{array}{c}-0.055^{* *} \\
(0.024)\end{array}$ & $\begin{array}{c}-0.049^{* * *} \\
(0.018)\end{array}$ & $\begin{array}{l}-0.005 \\
(0.013)\end{array}$ & $\begin{array}{c}-0.060^{* *} \\
(0.024)\end{array}$ & $\begin{array}{l}0.030^{*} \\
(0.017)\end{array}$ \\
\hline Age $45-64$ & $\begin{array}{l}0.046 \\
(0.028)\end{array}$ & $\begin{array}{l}-0.034 \\
(0.022)\end{array}$ & $\begin{array}{l}-0.020 \\
(0.017)\end{array}$ & $\begin{array}{c}0.014 \\
(0.012)\end{array}$ & $\begin{array}{l}-0.046^{*} \\
(0.024)\end{array}$ & $\begin{array}{c}0.020 \\
(0.017)\end{array}$ \\
\hline Female & $\begin{array}{l}-0.006 \\
(0.022)\end{array}$ & $\begin{array}{l}-0.016 \\
(0.017)\end{array}$ & $\begin{array}{l}0.030^{* *} \\
(0.013)\end{array}$ & $\begin{array}{c}-0.040^{* * *} \\
(0.009)\end{array}$ & $\begin{array}{c}0.012 \\
(0.017)\end{array}$ & $\begin{array}{l}-0.018 \\
(0.012)\end{array}$ \\
\hline Married & $\begin{array}{l}0.004 \\
(0.027)\end{array}$ & $\begin{array}{c}0.022 \\
(0.021)\end{array}$ & $\begin{array}{c}-0.051^{* * *} \\
(0.015)\end{array}$ & $\begin{array}{c}0.031^{* * *} \\
(0.010)\end{array}$ & $\begin{array}{l}-0.007 \\
(0.070)\end{array}$ & $\begin{array}{l}-0.019 \\
(0.049)\end{array}$ \\
\hline Black & $\begin{array}{l}-0.035 \\
(0.038)\end{array}$ & $\begin{array}{c}-0.102^{* * *} \\
(0.029)\end{array}$ & $\begin{array}{c}0.034 \\
(0.023)\end{array}$ & $\begin{array}{c}-0.035^{* *} \\
(0.016)\end{array}$ & $\begin{array}{c}0.024 \\
(0.023)\end{array}$ & $\begin{array}{c}-0.040^{* *} \\
(0.016)\end{array}$ \\
\hline Hispanic & $\begin{array}{l}0.118^{* *} \\
(0.056)\end{array}$ & $\begin{array}{c}-0.192^{* * *} \\
(0.043)\end{array}$ & $\begin{array}{c}0.057^{* * *} \\
(0.023)\end{array}$ & $\begin{array}{c}-0.044^{* * *} \\
(0.016)\end{array}$ & $\begin{array}{c}0.032 \\
(0.022)\end{array}$ & $\begin{array}{c}-0.071^{* * *} \\
(0.016)\end{array}$ \\
\hline Some College & $\begin{array}{l}0.001 \\
(0.028)\end{array}$ & $\begin{array}{c}0.019 \\
(0.021)\end{array}$ & $\begin{array}{c}0.075^{* * *} \\
(0.016)\end{array}$ & $\begin{array}{l}-0.017 \\
(0.011)\end{array}$ & $\begin{array}{l}-0.011 \\
(0.020)\end{array}$ & $\begin{array}{c}0.016 \\
(0.014)\end{array}$ \\
\hline Bachelor's Degree & $\begin{array}{l}-0.019 \\
(0.028)\end{array}$ & $\begin{array}{c}0.011 \\
(0.021)\end{array}$ & $\begin{array}{c}0.102^{* * *} \\
(0.017)\end{array}$ & $\begin{array}{c}-0.031^{* * *} \\
(0.012)\end{array}$ & $\begin{array}{c}0.031 \\
(0.023)\end{array}$ & $\begin{array}{l}-0.008 \\
(0.016)\end{array}$ \\
\hline $\begin{array}{l}\text { Income Less } \\
\text { Than } \$ 20,000\end{array}$ & $\begin{array}{l}0.038 \\
(0.056)\end{array}$ & $\begin{array}{l}-0.014 \\
(0.043)\end{array}$ & $\begin{array}{c}0.021 \\
(0.030)\end{array}$ & $\begin{array}{l}-0.022 \\
(0.021)\end{array}$ & $\begin{array}{c}0.038 \\
(0.040)\end{array}$ & $\begin{array}{l}-0.029 \\
(0.028)\end{array}$ \\
\hline $\begin{array}{l}\text { Income Between } \\
\$ 20,000 \text { and } \$ 40,000\end{array}$ & $\begin{array}{l}0.045 \\
(0.044)\end{array}$ & $\begin{array}{c}-0.060^{*} \\
(0.034)\end{array}$ & $\begin{array}{c}-0.056^{* *} \\
(0.025)\end{array}$ & $\begin{array}{c}0.024 \\
(0.018)\end{array}$ & $\begin{array}{l}-0.023 \\
(0.039)\end{array}$ & $\begin{array}{c}0.002 \\
(0.027)\end{array}$ \\
\hline $\begin{array}{l}\text { Income Between } \\
\$ 40,000 \text { and } \$ 80,000\end{array}$ & $\begin{array}{l}-0.004 \\
(0.033)\end{array}$ & $\begin{array}{l}-0.026 \\
(0.025)\end{array}$ & $\begin{array}{c}-0.067^{* * *} \\
(0.022)\end{array}$ & $\begin{array}{c}0.026 \\
(0.016)\end{array}$ & $\begin{array}{l}-0.052 \\
(0.037)\end{array}$ & $\begin{array}{c}0.023 \\
(0.026)\end{array}$ \\
\hline $\begin{array}{l}\text { Income Between } \\
\$ 80,000 \text { and } \$ 120,000\end{array}$ & $\begin{array}{l}-0.031 \\
(0.037)\end{array}$ & $\begin{array}{l}-0.049^{*} \\
(0.028)\end{array}$ & $\begin{array}{c}-0.059^{* *} \\
(0.025)\end{array}$ & $\begin{array}{l}0.038^{* *} \\
(0.017)\end{array}$ & $\begin{array}{l}-0.026 \\
(0.040)\end{array}$ & $\begin{array}{l}-0.011 \\
(0.028)\end{array}$ \\
\hline Unemployed & $\begin{array}{l}-0.078 \\
(0.062)\end{array}$ & $\begin{array}{l}-0.050 \\
(0.048)\end{array}$ & $\begin{array}{c}0.102^{* * *} \\
(0.026)\end{array}$ & $\begin{array}{c}-0.046^{* *} \\
(0.018)\end{array}$ & $\begin{array}{l}0.079^{* *} \\
(0.032)\end{array}$ & $\begin{array}{l}-0.030 \\
(0.023)\end{array}$ \\
\hline $\begin{array}{l}\text { Days Driving } \\
\text { Per Week }\end{array}$ & $\begin{array}{l}-0.018^{* * *} \\
(0.006)\end{array}$ & $\begin{array}{l}0.008 \\
(0.004)\end{array}$ & & & & \\
\hline $\begin{array}{l}\text { Notice Gas Prices } \\
\text { Per Week }\end{array}$ & $\begin{array}{l}-0.009^{* *} \\
(0.005)\end{array}$ & $\begin{array}{c}0.016 \\
(0.004)\end{array}$ & & & & \\
\hline Constant & $\begin{array}{l}0.242^{* * *} \\
(0.061)\end{array}$ & $\begin{array}{c}-0.252^{* * *} \\
(0.047)\end{array}$ & $\begin{array}{c}0.094^{* * *} \\
(0.034)\end{array}$ & $\begin{array}{c}-0.256^{* * *} \\
(0.024)\end{array}$ & $\begin{array}{c}0.174^{* * *} \\
(0.046)\end{array}$ & $\begin{array}{c}-0.300^{* * *} \\
(0.033)\end{array}$ \\
\hline
\end{tabular}

Notes: ${ }^{* * *},{ }^{* *},{ }^{*}$ denote statistical significance at the $1 \%, 5 \%$ and $10 \%$ level respectively. Regressions also include minor and missing party, church attendance, union membership, and missing income indicators. The omitted categories are Republicans, age $65+$, male, not married, white, 12 years or less of education, $\$ 120,000+$ for income, employed, not in union, and do not attend church. All regression estimated using OLS. 
Table 2: Correlates of Reported Unemployment Rate in 2008 CCES

\begin{tabular}{|c|c|c|c|c|c|c|}
\hline \multirow{2}{*}{$\begin{array}{l}\text { Dependent Variable } \\
\text { Sample }\end{array}$} & \multicolumn{3}{|c|}{ Level (LAD) } & \multicolumn{3}{|c|}{ Percentile (OLS) } \\
\hline & $\begin{array}{l}\text { Bench- } \\
\text { marked }\end{array}$ & $\begin{array}{l}\text { Non-bench- } \\
\text { marked }\end{array}$ & Difference & $\begin{array}{l}\text { Bench- } \\
\text { marked }\end{array}$ & $\begin{array}{l}\text { Non-bench- } \\
\text { marked }\end{array}$ & Difference \\
\hline Democrat & $\begin{array}{c}0.55^{* * *} \\
(0.07)\end{array}$ & $\begin{array}{c}1.55^{* * *} \\
(0.46)\end{array}$ & $\begin{array}{c}-0.99^{* *} \\
(0.47)\end{array}$ & $\begin{array}{c}11.95^{* * *} \\
(1.21)\end{array}$ & $\begin{array}{c}9.40^{* * *} \\
(1.53)\end{array}$ & $\begin{array}{c}2.54 \\
(1.95)\end{array}$ \\
\hline Independent & $\begin{array}{c}0.30^{* * *} \\
(0.06)\end{array}$ & $\begin{array}{c}0.55 \\
(0.37)\end{array}$ & $\begin{array}{l}-0.25 \\
(0.37)\end{array}$ & $\begin{array}{c}7.95^{* * *} \\
(1.05)\end{array}$ & $\begin{array}{l}4.54^{* *} \\
(1.80)\end{array}$ & $\begin{array}{c}3.41 \\
(2.09)\end{array}$ \\
\hline Age $18-24$ & $\begin{array}{c}0.69 \\
(0.49)\end{array}$ & $\begin{array}{l}12.18^{*} \\
(6.50)\end{array}$ & $\begin{array}{c}-11.49^{*} \\
(6.52)\end{array}$ & $\begin{array}{c}12.99^{* * *} \\
(2.75)\end{array}$ & $\begin{array}{c}16.31^{* * *} \\
(4.06)\end{array}$ & $\begin{array}{l}-3.31 \\
(4.91)\end{array}$ \\
\hline Age $25-44$ & $\begin{array}{c}0.50^{* * *} \\
(0.08)\end{array}$ & $\begin{array}{l}1.64^{* *} \\
(0.79)\end{array}$ & $\begin{array}{l}-1.14 \\
(0.80)\end{array}$ & $\begin{array}{c}10.51^{* * *} \\
(1.61)\end{array}$ & $\begin{array}{c}10.42^{* * *} \\
(2.37)\end{array}$ & $\begin{array}{c}0.09 \\
(2.87)\end{array}$ \\
\hline Age $45-64$ & $\begin{array}{c}0.21^{* * *} \\
(0.06)\end{array}$ & $\begin{array}{c}0.64 \\
(0.49)\end{array}$ & $\begin{array}{l}-0.42 \\
(0.49)\end{array}$ & $\begin{array}{c}5.01^{* * *} \\
(1.34)\end{array}$ & $\begin{array}{c}6.32^{* * *} \\
(1.74)\end{array}$ & $\begin{array}{l}-1.30 \\
(2.19)\end{array}$ \\
\hline Married Male & $\begin{array}{l}0.17^{* *} \\
(0.07)\end{array}$ & $\begin{array}{l}1.00 \\
(0.59)\end{array}$ & $\begin{array}{l}-0.83 \\
(0.59)\end{array}$ & $\begin{array}{c}0.15 \\
(1.46)\end{array}$ & $\begin{array}{l}1.29 \\
(2.81)\end{array}$ & $\begin{array}{l}-1.14 \\
(3.16)\end{array}$ \\
\hline Unmarried Female & $\begin{array}{c}0.65^{* * *} \\
(0.10)\end{array}$ & $\begin{array}{l}3.09^{* *} \\
(1.29)\end{array}$ & $\begin{array}{l}-2.44^{*} \\
(1.29)\end{array}$ & $\begin{array}{c}11.58^{* * *} \\
(1.53)\end{array}$ & $\begin{array}{c}11.84^{* * *} \\
(3.32)\end{array}$ & $\begin{array}{l}-0.26 \\
(3.66)\end{array}$ \\
\hline Married Female & $\begin{array}{c}0.63^{* * *} \\
(0.11)\end{array}$ & $\begin{array}{l}3.00^{* *} \\
(1.03)\end{array}$ & $\begin{array}{r}-2.37^{* *} \\
(1.04)\end{array}$ & $\begin{array}{c}10.42^{* * *} \\
(1.38)\end{array}$ & $\begin{array}{c}16.79^{* * *} \\
(2.57)\end{array}$ & $\begin{array}{c}-6.37^{* *} \\
(2.92)\end{array}$ \\
\hline Black & $\begin{array}{l}0.59^{* *} \\
(0.24)\end{array}$ & $\begin{array}{l}1.55 \\
(2.87)\end{array}$ & $\begin{array}{l}-0.95 \\
(2.88)\end{array}$ & $\begin{array}{c}6.93^{* * *} \\
(1.43)\end{array}$ & $\begin{array}{l}6.17^{* *} \\
(2.97)\end{array}$ & $\begin{array}{c}0.76 \\
(3.30)\end{array}$ \\
\hline Hispanic & $\begin{array}{c}0.06 \\
(0.13)\end{array}$ & $\begin{array}{c}1.27 \\
(1.50)\end{array}$ & $\begin{array}{l}-1.21 \\
(1.50)\end{array}$ & $\begin{array}{c}0.07 \\
(2.15)\end{array}$ & $\begin{array}{c}4.17 \\
(2.71)\end{array}$ & $\begin{array}{l}-4.10 \\
(3.46)\end{array}$ \\
\hline Some College & $\begin{array}{c}-0.28^{* * *} \\
(0.07)\end{array}$ & $\begin{array}{c}-1.73^{* *} \\
(0.90)\end{array}$ & $\begin{array}{l}1.45^{*} \\
(0.90)\end{array}$ & $\begin{array}{c}-4.98^{* * *} \\
(1.16)\end{array}$ & $\begin{array}{c}-8.49^{* * *} \\
(2.68)\end{array}$ & $\begin{array}{c}3.52 \\
(2.92)\end{array}$ \\
\hline Bachelor's Degree & $\begin{array}{c}-0.35^{* * *} \\
(0.07)\end{array}$ & $\begin{array}{c}-2.00^{* *} \\
(0.96)\end{array}$ & $\begin{array}{c}1.65 \\
(0.96)\end{array}$ & $\begin{array}{c}-7.11^{* * *} \\
(1.27)\end{array}$ & $\begin{array}{c}-13.21^{* * *} \\
(2.50)\end{array}$ & $\begin{array}{l}6.10^{* *} \\
(2.81)\end{array}$ \\
\hline $\begin{array}{l}\text { Income Less } \\
\text { Than } \$ 20,000\end{array}$ & $\begin{array}{c}0.74^{* * *} \\
(0.21)\end{array}$ & $\begin{array}{c}13.36^{* *} \\
(5.62)\end{array}$ & $\begin{array}{c}-12.62^{* *} \\
(5.62)\end{array}$ & $\begin{array}{c}10.70^{* * *} \\
(2.34)\end{array}$ & $\begin{array}{c}19.29^{* * *} \\
(5.77)\end{array}$ & $\begin{array}{l}-8.59 \\
(6.23)\end{array}$ \\
\hline $\begin{array}{l}\text { Income Between } \\
\$ 20,000 \text { and } \$ 40,000\end{array}$ & $\begin{array}{c}0.42^{* * *} \\
(0.10)\end{array}$ & $\begin{array}{l}3.18^{*} \\
(1.67)\end{array}$ & $\begin{array}{l}-2.76 \\
(1.67)\end{array}$ & $\begin{array}{l}6.68^{* * *} \\
(1.73)\end{array}$ & $\begin{array}{c}14.49^{* * *} \\
(3.54)\end{array}$ & $\begin{array}{c}-7.81^{* * *} \\
(3.94)\end{array}$ \\
\hline $\begin{array}{l}\text { Income Between } \\
\$ 40,000 \text { and } \$ 80,000\end{array}$ & $\begin{array}{c}0.05 \\
(0.06)\end{array}$ & $\begin{array}{c}0.55 \\
(0.63)\end{array}$ & $\begin{array}{l}-0.49 \\
(0.64)\end{array}$ & $\begin{array}{l}2.97^{*} \\
(1.50)\end{array}$ & $\begin{array}{l}6.33^{* *} \\
(2.65)\end{array}$ & $\begin{array}{l}-3.36 \\
(3.05)\end{array}$ \\
\hline $\begin{array}{l}\text { Income Between } \\
\$ 80,000 \text { and } \$ 120,000\end{array}$ & $\begin{array}{c}0.04 \\
(0.06)\end{array}$ & $\begin{array}{c}0.55 \\
(0.57)\end{array}$ & $\begin{array}{l}-0.50 \\
(0.58)\end{array}$ & $\begin{array}{c}0.92 \\
(1.71)\end{array}$ & $\begin{array}{c}3.27 \\
(2.73)\end{array}$ & $\begin{array}{l}-2.36 \\
(3.23)\end{array}$ \\
\hline Unemployed & $\begin{array}{c}0.18 \\
(0.18)\end{array}$ & $\begin{array}{c}0.27 \\
(2.41)\end{array}$ & $\begin{array}{l}-0.09 \\
(2.42)\end{array}$ & $\begin{array}{c}2.85 \\
(1.83)\end{array}$ & $\begin{array}{c}2.53 \\
(3.01)\end{array}$ & $\begin{array}{c}0.32 \\
(3.52)\end{array}$ \\
\hline State Unemployment & $\begin{array}{c}0.11^{* * *} \\
(0.02)\end{array}$ & $\begin{array}{c}0.00 \\
(0.14)\end{array}$ & $\begin{array}{c}0.11 \\
(0.14)\end{array}$ & $\begin{array}{c}2.33^{* * *} \\
(0.37)\end{array}$ & $\begin{array}{c}0.42 \\
(0.61)\end{array}$ & $\begin{array}{c}1.91 \\
(0.72)\end{array}$ \\
\hline Constant & $\begin{array}{c}5.04^{* * *} \\
(0.18)\end{array}$ & $\begin{array}{c}4.27 \\
(1.44)\end{array}$ & & $\begin{array}{c}17.10^{* * *} \\
(3.94)\end{array}$ & $\begin{array}{c}24.05^{* * *} \\
(5.83)\end{array}$ & \\
\hline
\end{tabular}

Notes: ${ }^{* * *},{ }^{* *},{ }^{*}$ denote statistical significance at the $1 \%, 5 \%$ and $10 \%$ level respectively, with standard errors block bootstraped by state in LAD regressions and clustered by state in OLS regressions. benchmarked: $\mathrm{N}=2,918$; non-benchmarked: $\mathrm{N}=957$. Regressions also include minor and missing party, church attendance, union membership, and missing income indicators. The omitted categories are Republicans, age $65+$, male, not married, white, 12 years or less of education, $\$ 120,000+$ for income, employed, not in union, and do not attend church. 
Table 3: Correlates of Qualitative Economic Assessments in 2008 Benchmarked CCES

\begin{tabular}{|c|c|c|c|}
\hline Dependent Variable & $\begin{array}{c}\text { Retrospective Economic } \\
\text { Evaluation }\end{array}$ & $\begin{array}{l}\text { Business } \\
\text { Conditions }\end{array}$ & $\begin{array}{c}\text { Employment } \\
\text { Situation }\end{array}$ \\
\hline Democrat & $\begin{array}{c}0.54^{* * *} \\
(0.03)\end{array}$ & $\begin{array}{c}0.42^{* * *} \\
(0.02)\end{array}$ & $\begin{array}{c}0.39^{* * *} \\
(0.03)\end{array}$ \\
\hline Independent & $\begin{array}{c}0.31^{* * *} \\
(0.04)\end{array}$ & $\begin{array}{c}0.19^{* * *} \\
(0.03)\end{array}$ & $\begin{array}{c}0.22^{* * *} \\
(0.03)\end{array}$ \\
\hline Age $18-24$ & $\begin{array}{l}-0.09 \\
(0.06)\end{array}$ & $\begin{array}{c}-0.20^{* * *} \\
(0.06)\end{array}$ & $\begin{array}{l}-0.01 \\
(0.06)\end{array}$ \\
\hline Age $25-44$ & $\begin{array}{l}-0.05 \\
(0.04)\end{array}$ & $\begin{array}{c}0.02 \\
(0.04)\end{array}$ & $\begin{array}{c}0.02 \\
(0.05)\end{array}$ \\
\hline Age $45-64$ & $\begin{array}{l}-0.00 \\
(0.02)\end{array}$ & $\begin{array}{l}0.07^{* *} \\
(0.04)\end{array}$ & $\begin{array}{l}0.07^{* *} \\
(0.03)\end{array}$ \\
\hline Married Male & $\begin{array}{c}-0.07^{* *} \\
(0.03)\end{array}$ & $\begin{array}{c}0.02 \\
(0.04)\end{array}$ & $\begin{array}{c}0.02 \\
(0.04)\end{array}$ \\
\hline Unmarried Female & $\begin{array}{c}0.02 \\
(0.04)\end{array}$ & $\begin{array}{l}0.07^{* *} \\
(0.03)\end{array}$ & $\begin{array}{c}0.03 \\
(0.05)\end{array}$ \\
\hline Married Female & $\begin{array}{c}-0.09^{* * *} \\
(0.03)\end{array}$ & $\begin{array}{l}-0.01 \\
(0.04)\end{array}$ & $\begin{array}{c}0.01 \\
(0.04)\end{array}$ \\
\hline Black & $\begin{array}{l}-0.02 \\
(0.03)\end{array}$ & $\begin{array}{l}-0.05 \\
(0.04)\end{array}$ & $\begin{array}{c}0.05 \\
(0.04)\end{array}$ \\
\hline Hispanic & $\begin{array}{c}-0.11^{* *} \\
(0.04)\end{array}$ & $\begin{array}{c}-0.08^{* *} \\
(0.03)\end{array}$ & $\begin{array}{l}-0.02 \\
(0.06)\end{array}$ \\
\hline Some College & $\begin{array}{c}0.04 \\
(0.03)\end{array}$ & $\begin{array}{c}0.01 \\
(0.03)\end{array}$ & $\begin{array}{c}0.00 \\
(0.03)\end{array}$ \\
\hline Bachelor's Degree & $\begin{array}{c}0.03 \\
(0.03)\end{array}$ & $\begin{array}{c}0.00 \\
(0.03)\end{array}$ & $\begin{array}{l}-0.02 \\
(0.03)\end{array}$ \\
\hline $\begin{array}{l}\text { Income Less } \\
\text { Than } \$ 20,000\end{array}$ & $\begin{array}{l}-0.08 \\
(0.06)\end{array}$ & $\begin{array}{c}0.04 \\
(0.06)\end{array}$ & $\begin{array}{c}0.31^{* * *} \\
(0.08)\end{array}$ \\
\hline $\begin{array}{l}\text { Income Between } \\
\$ 20,000 \text { and } \$ 40,000\end{array}$ & $\begin{array}{c}-0.10^{* *} \\
(0.05)\end{array}$ & $\begin{array}{c}0.02 \\
(0.04)\end{array}$ & $\begin{array}{c}0.24^{* * *} \\
(0.04)\end{array}$ \\
\hline $\begin{array}{l}\text { Income Between } \\
\$ 40,000 \text { and } \$ 80,000\end{array}$ & $\begin{array}{l}-0.03 \\
(0.04)\end{array}$ & $\begin{array}{l}-0.04 \\
(0.04)\end{array}$ & $\begin{array}{c}0.11^{* * *} \\
(0.04)\end{array}$ \\
\hline $\begin{array}{l}\text { Income Between } \\
\$ 80,000 \text { and } \$ 120,000\end{array}$ & $\begin{array}{l}-0.03 \\
(0.05)\end{array}$ & $\begin{array}{c}-0.08^{* *} \\
(0.04)\end{array}$ & $\begin{array}{c}0.03 \\
(0.04)\end{array}$ \\
\hline Unemployed & $\begin{array}{c}0.03 \\
(0.05)\end{array}$ & $\begin{array}{c}0.15^{* * *} \\
(0.05)\end{array}$ & $\begin{array}{c}0.19^{* * *} \\
(0.06)\end{array}$ \\
\hline State Unemployment & $\begin{array}{c}0.01 \\
(0.01)\end{array}$ & $\begin{array}{c}0.18^{* * *} \\
(0.03)\end{array}$ & $\begin{array}{c}0.09^{* * *} \\
(0.01)\end{array}$ \\
\hline Constant & $\begin{array}{c}4.37^{* * *} \\
(0.08)\end{array}$ & $\begin{array}{c}1.66^{* * *} \\
(0.11)\end{array}$ & $\begin{array}{c}1.31^{* * *} \\
(0.11)\end{array}$ \\
\hline
\end{tabular}

Notes: $^{* * *},{ }^{* *},{ }^{*}$ denote statistical significance at the $1 \%, 5 \%$ and $10 \%$ level respectively with robust standard errors clustered at the state level. $\mathrm{N}=2,918$. Regressions also include minor and missing party, church attendance, union membership, and missing income indicators. The omitted categories are Republicans, age 65+, male, not married, white, 12 years or less of education, $\$ 120,000+$ for income, employed, not in union, and do not attend church. 
Table 4: Unemployment Assessments by Party in 2008 Benchmarked CCES

\begin{tabular}{cccc}
\hline \hline & \multicolumn{3}{c}{ Partisan Identification } \\
& Republican & Independent & Democratic \\
\hline Qualitative & & & \\
Unemployment Evaluation: & & & \\
Positive (N=446) & $28.1 \%$ & 16.4 & 5.8 \\
Neutral (N=1429) & $52.0 \%$ & 48.6 & 51.2 \\
Negative (N=951) & $19.9 \%$ & 35.0 & 43.1 \\
& & & \\
Unemployment Rate: & & & 10.2 \\
Less than 5.6 (N=443) & $24.7 \%$ & 13.9 & 49.3 \\
Between 5.6 and 7.0 (N=1488) & $53.4 \%$ & 55.9 & 40.5 \\
Greater than 7.0 (N=895) & $21.8 \%$ & 30.2 & \\
\hline \hline
\end{tabular}

Notes: Numbers are percent of the column total.

Table 5: Conditional Distribution of Reported Unemployment Rates in 2008 Benchmarked CCES

\begin{tabular}{cccc}
\hline \hline & 25th Percentile & 50th Percentile & 75th Percentile \\
\hline $\begin{array}{l}\text { Qualitative } \\
\text { Unemployment Evaluation: }\end{array}$ & & & \\
Positive: & & & \\
Republican & $5.2 \%$ & 6.0 & 6.3 \\
Independent & $5.5 \%$ & 6.1 & 7.0 \\
Democratic & $6.0 \%$ & 6.5 & 8.0 \\
Neutral: & & & \\
Republican & $5.8 \%$ & 6.0 & 7.0 \\
Independent & $6.0 \%$ & 6.4 & 7.5 \\
Democratic & $6.0 \%$ & 7.0 & 8.5 \\
Negative: & & & 10.0 \\
Republican & $6.0 \%$ & 7.0 & 10.0 \\
Independent & $6.1 \%$ & 7.0 & \\
Democratic & $6.1 \%$ & 7.0 & \\
\hline \hline
\end{tabular}

Figures and Tables-8 


\section{Appendix Not Intended for Publication}

Between October 2008 and October 2009 the national unemployment rate increased from $6.5 \%$ to $10.2 \%$. Additionally, Barack Obama (a Democrat) replaced George W. Bush (a Republican) in the White House. Did the types of individuals reporting relatively higher unemployment rates change from 2008 to 2009 as the economy worsened? Did partisan perceptions of the unemployment rate change with the party of the President?

Table A.1 shows a shift in how partisan identification relates to reported unemployment between 2008 and 2009. Whereas the median Democrat reported unemployment rates that were 0.55 percentage points $($ s.e. $=0.07$ ) higher than the median Republican in 2008 , the median Democrat reported unemployment rates that were 0.06 percentage points (s.e. $=$ 0.15) lower than the median Republican in 2009. This finding is consistent with previous work showing that partisan attachments affect economic evaluations (Wlezien, Franklin and Twiggs, 1997; Anderson, Mendes and Tverdova, 2004; Evans and Andersen, 2006; Evans and Pickup, 2010).

Table A.1 also shows a number of differences in how demographics relate to reported unemployment in the 2008 and 2009 benchmarked CCES sample. First, respondents who did not attend college were relatively more negative about unemployment than those who attended college. In 2008, the median reported unemployment rate by respondents who had never attended college was 0.35 percentage points (s.e. $=0.07$ ) higher than the median reported unemployment rate for respondents with a Bachelor's degree. In 2009, this gap increased to 1.10 percentage points $($ s.e. $=0.43)$. The point estimates in this table further show that Black and Hispanic respondents also became relatively more pessimistic about employment between 2008 and 2009, although these differences are not statistically significant at conventional levels. Unlike 2008, when younger respondents reported higher unemployment rates, we observe no differences across age groups in reported unemployment in 2009. Residents of states with more unemployment continued to report statistically significant higher unemployment rates in 2009, although the relationship is somewhat weaker 
than in 2008.

We also compare the correlates of reported unemployment rates on the CCES with the correlates of reported unemployment rates on the ANES. As noted in the text, the 2006 and 2008 ANES also contained questions about the unemployment rate. The question on both surveys did not contain a benchmark, and the 2006 question differed slightly, as it asked respondents their perceptions of the unemployment rate in their state of residence. The results reported in Table A.2 show very similar patterns to those observed in the CCES. Not surprisingly, the point estimate on the effect of the state unemployment rate is larger in 2006 when the question is about state unemployment. The robustness of the results across time and survey suggest that the differences across groups in perceptions of unemployment are likely to hold in a wide variety of contexts.

The final table in the appendix provides statistical tests of the patterns observed in Figure 4. The patterns in Table A.3 show that the same general relationship holds between reported unemployment and qualitative assessments within the boundaries of the historical benchmarks in both the benchmarked and non-benchmarked sample. The first column shows that reported unemployment rates below $10.8 \%$ significantly relate to qualitative evaluations of the employment situation in the benchmarked sample, with a one percentage point increase in the reported unemployment rate associating with a 0.104 (s.e. $=0.010$ ) units more negative qualitative evaluation of the employment situation. Similarly, the second column shows that a one percentage point increase in reported unemployment rates below $10.8 \%$ associates with a 0.071 (s.e. $=0.023$ ) unit more negative qualitative evaluation of the employment situation in the non-benchmarked sample. We cannot reject the null that the difference between these two coefficients in the benchmarked and non-benchmarked sample, 0.033 (s.e. $=0.025)$, is statistically indistinguishable from zero at conventional levels. Similar patterns are found when we change our dependent variable to be retrospective economic evaluations, business conditions, or reporting a vote for Obama. These results are consistent with our hypothesis that our benchmark should not substantively change the relationship 
between reported unemployment and measures we expect to associate with reported unemployment.

The patterns in Table A.3 also show that there is no statistical relationship between the reported unemployment above the historical maximum and qualitative evaluations in the benchmarked sample. These results are consistent with the respondents who report unemployment rates above the upper bound of the benchmark not attempting to answer the question. 
Table A.1: Correlates of Reported Unemployment Rate in Benchmarked 2008 and 2009 CCES

\begin{tabular}{|c|c|c|c|c|c|c|}
\hline \multirow[t]{2}{*}{ Dependent Variable } & \multicolumn{3}{|c|}{ Level (LAD) } & \multicolumn{3}{|c|}{ Percentile (OLS) } \\
\hline & 2008 & 2009 & Difference & 2008 & 2009 & Difference \\
\hline Democrat & $\begin{array}{l}0.55^{* * *} \\
(0.07)\end{array}$ & $\begin{array}{l}-0.06 \\
(0.15)\end{array}$ & $\begin{array}{c}0.61^{* * *} \\
(0.17)\end{array}$ & $\begin{array}{c}11.95^{* * *} \\
(1.21)\end{array}$ & $\begin{array}{l}-3.83 \\
(2.40)\end{array}$ & $\begin{array}{c}15.78^{* * *} \\
(2.68)\end{array}$ \\
\hline Independent & $\begin{array}{l}0.30^{* * *} \\
(0.06)\end{array}$ & $\begin{array}{c}0.19 \\
(0.18)\end{array}$ & $\begin{array}{c}0.10 \\
(0.19)\end{array}$ & $\begin{array}{l}7.95^{* * *} \\
(1.05)\end{array}$ & $\begin{array}{c}3.43 \\
(2.31)\end{array}$ & $\begin{array}{l}4.53^{*} \\
(2.54)\end{array}$ \\
\hline Age $18-24$ & $\begin{array}{l}0.69 \\
(0.49)\end{array}$ & $\begin{array}{c}0.07 \\
(0.39)\end{array}$ & $\begin{array}{c}0.62 \\
(0.63)\end{array}$ & $\begin{array}{c}12.99^{* * *} \\
(2.75)\end{array}$ & $\begin{array}{l}-1.17 \\
(5.26)\end{array}$ & $\begin{array}{c}14.16^{* *} \\
(5.94)\end{array}$ \\
\hline Age $25-44$ & $\begin{array}{l}0.50^{* * *} \\
(0.08)\end{array}$ & $\begin{array}{l}-0.02 \\
(0.23)\end{array}$ & $\begin{array}{l}0.52^{* *} \\
(0.25)\end{array}$ & $\begin{array}{c}10.51^{* * *} \\
(1.61)\end{array}$ & $\begin{array}{l}-1.36 \\
(2.65)\end{array}$ & $\begin{array}{c}11.87^{* * *} \\
(3.11)\end{array}$ \\
\hline Age $45-64$ & $\begin{array}{l}0.21^{* * *} \\
(0.06)\end{array}$ & $\begin{array}{l}-0.08 \\
(0.24)\end{array}$ & $\begin{array}{c}0.29 \\
(0.24)\end{array}$ & $\begin{array}{c}5.01^{* * *} \\
(1.34)\end{array}$ & $\begin{array}{l}-2.93 \\
(3.01)\end{array}$ & $\begin{array}{l}7.95^{* *} \\
(3.29)\end{array}$ \\
\hline Married Male & $\begin{array}{l}0.17^{* *} \\
(0.07)\end{array}$ & $\begin{array}{l}0.39^{*} \\
(0.22)\end{array}$ & $\begin{array}{l}-0.22 \\
(0.23)\end{array}$ & $\begin{array}{c}0.15 \\
(1.46)\end{array}$ & $\begin{array}{c}7.23^{* * *} \\
(2.44)\end{array}$ & $\begin{array}{c}-7.08^{* *} \\
(2.85)\end{array}$ \\
\hline Unmarried Female & $\begin{array}{l}0.65^{* * *} \\
(0.10)\end{array}$ & $\begin{array}{c}0.32 \\
(0.22)\end{array}$ & $\begin{array}{c}0.33 \\
(0.24)\end{array}$ & $\begin{array}{c}11.58^{* * *} \\
(1.53)\end{array}$ & $\begin{array}{l}6.66^{* *} \\
(2.98)\end{array}$ & $\begin{array}{c}4.92 \\
(3.35)\end{array}$ \\
\hline Married Female & $\begin{array}{l}0.63^{* * *} \\
(0.11)\end{array}$ & $\begin{array}{l}0.64^{* *} \\
(0.28)\end{array}$ & $\begin{array}{l}-0.01 \\
(0.30)\end{array}$ & $\begin{array}{c}10.42^{* * *} \\
(1.38)\end{array}$ & $\begin{array}{c}10.98^{* * *} \\
(2.75)\end{array}$ & $\begin{array}{l}-0.56 \\
(3.08)\end{array}$ \\
\hline Black & $\begin{array}{l}0.59^{* *} \\
(0.24)\end{array}$ & $\begin{array}{c}0.82 \\
(0.58)\end{array}$ & $\begin{array}{l}-0.23 \\
(0.63)\end{array}$ & $\begin{array}{c}6.93^{* * *} \\
(1.43)\end{array}$ & $\begin{array}{c}12.19^{* * *} \\
(3.03)\end{array}$ & $\begin{array}{l}-5.26 \\
(3.35)\end{array}$ \\
\hline Hispanic & $\begin{array}{l}0.06 \\
(0.13)\end{array}$ & $\begin{array}{c}0.12 \\
(0.24)\end{array}$ & $\begin{array}{l}-0.06 \\
(0.27)\end{array}$ & $\begin{array}{c}0.07 \\
(2.15)\end{array}$ & $\begin{array}{c}1.24 \\
(2.79)\end{array}$ & $\begin{array}{l}-1.17 \\
(3.52)\end{array}$ \\
\hline Some College & $\begin{array}{l}-0.28^{* * *} \\
(0.07)\end{array}$ & $\begin{array}{c}-0.99^{* *} \\
(0.42)\end{array}$ & $\begin{array}{l}0.71^{*} \\
(0.42)\end{array}$ & $\begin{array}{c}-4.98^{* * *} \\
(1.16)\end{array}$ & $\begin{array}{c}-11.56^{* * *} \\
(2.21)\end{array}$ & $\begin{array}{c}6.59^{* * *} \\
(2.49)\end{array}$ \\
\hline Bachelor's Degree & $\begin{array}{l}-0.35^{* * *} \\
(0.07)\end{array}$ & $\begin{array}{c}-1.10^{* *} \\
(0.43)\end{array}$ & $\begin{array}{l}0.74^{*} \\
(0.44)\end{array}$ & $\begin{array}{c}-7.11^{* * *} \\
(1.27)\end{array}$ & $\begin{array}{c}-13.06^{* * *} \\
(2.35)\end{array}$ & $\begin{array}{l}5.95^{* *} \\
(2.68)\end{array}$ \\
\hline $\begin{array}{l}\text { Income Less } \\
\text { Than } \$ 20,000\end{array}$ & $\begin{array}{l}0.74^{* * *} \\
(0.21)\end{array}$ & $\begin{array}{c}0.88 \\
(1.69)\end{array}$ & $\begin{array}{l}-0.14 \\
(1.71)\end{array}$ & $\begin{array}{c}10.70^{* * *} \\
(2.34)\end{array}$ & $\begin{array}{c}8.24^{* * *} \\
(3.72)\end{array}$ & $\begin{array}{c}2.45 \\
(4.40)\end{array}$ \\
\hline $\begin{array}{l}\text { Income Between } \\
\$ 20,000 \text { and } \$ 40,000\end{array}$ & $\begin{array}{l}0.42^{* * *} \\
(0.10)\end{array}$ & $\begin{array}{c}0.03 \\
(0.33)\end{array}$ & $\begin{array}{c}0.39 \\
(0.34)\end{array}$ & $\begin{array}{c}6.68^{* * *} \\
(1.73)\end{array}$ & $\begin{array}{l}2.85 \\
(3.63)\end{array}$ & $\begin{array}{c}3.84 \\
(4.02)\end{array}$ \\
\hline $\begin{array}{l}\text { Income Between } \\
\$ 40,000 \text { and } \$ 80,000\end{array}$ & $\begin{array}{l}0.05 \\
(0.06)\end{array}$ & $\begin{array}{c}0.21 \\
(0.16)\end{array}$ & $\begin{array}{l}-0.16 \\
(0.17)\end{array}$ & $\begin{array}{l}2.97^{*} \\
(1.50)\end{array}$ & $\begin{array}{c}0.15 \\
(2.79)\end{array}$ & $\begin{array}{c}2.81 \\
(3.17)\end{array}$ \\
\hline $\begin{array}{l}\text { Income Between } \\
\$ 80,000 \text { and } \$ 120,000\end{array}$ & $\begin{array}{l}0.04 \\
(0.06)\end{array}$ & $\begin{array}{c}0.05 \\
(0.15)\end{array}$ & $\begin{array}{l}-0.01 \\
(0.16)\end{array}$ & $\begin{array}{c}0.92 \\
(1.71)\end{array}$ & $\begin{array}{c}0.89 \\
(3.01)\end{array}$ & $\begin{array}{c}0.03 \\
(3.46)\end{array}$ \\
\hline Unemployed & $\begin{array}{l}0.18 \\
(0.18)\end{array}$ & $\begin{array}{c}0.16 \\
(0.36)\end{array}$ & $\begin{array}{c}0.02 \\
(0.40)\end{array}$ & $\begin{array}{c}2.85 \\
(1.83)\end{array}$ & $\begin{array}{c}2.64 \\
(3.04)\end{array}$ & $\begin{array}{c}0.20 \\
(3.55)\end{array}$ \\
\hline State Unemployment & $\begin{array}{l}0.11^{* * *} \\
(0.02)\end{array}$ & $\begin{array}{l}0.07^{* *} \\
(0.03)\end{array}$ & $\begin{array}{c}0.04 \\
(0.04)\end{array}$ & $\begin{array}{l}2.33^{* * *} \\
(0.37)\end{array}$ & $\begin{array}{c}1.21^{* * *} \\
(0.39)\end{array}$ & $\begin{array}{l}1.12^{* *} \\
(0.54)\end{array}$ \\
\hline Constant & $\begin{array}{l}5.04^{* * *} \\
(0.18)\end{array}$ & $\begin{array}{c}10.04^{* * *} \\
(0.62)\end{array}$ & & $\begin{array}{c}17.10^{* * *} \\
(3.94)\end{array}$ & $\begin{array}{c}35.74^{* * *} \\
(5.84)\end{array}$ & \\
\hline
\end{tabular}

Notes: $^{* * *},{ }^{* *},{ }^{*}$ denote statistical significance at the $1 \%, 5 \%$ and $10 \%$ level respectively with robust standard errors block bootstraped by state in LAD regressions and clustered by state in OLS regressions. 2008: $\mathrm{N}=2,918 ; 2009$ : $\mathrm{N}=956$. Regressions also include minor and missing party, church attendance, union membership, and missing income indicators. The omitted categories are Republicans, age $65+$, male, not married, white, 12 years or less of education, $\$ 120,000+$ for income, employed, not in union, and do not attend church. 
Table A.2: Correlates of Reported Unemployment Rate in ANES

\begin{tabular}{|c|c|c|c|c|}
\hline \multirow[t]{2}{*}{ Dependent Variable } & \multicolumn{2}{|c|}{ Level (LAD) } & \multicolumn{2}{|c|}{ Percentile (OLS) } \\
\hline & 2006 & 2008 & 2006 & 2008 \\
\hline Democrat & $\begin{array}{l}2.29^{*} \\
(1.22)\end{array}$ & $\begin{array}{c}2.29 \\
(1.73)\end{array}$ & $\begin{array}{l}6.63^{* *} \\
(2.43)\end{array}$ & $\begin{array}{c}5.08^{* * *} \\
(1.46)\end{array}$ \\
\hline Independent & $\begin{array}{l}1.49 \\
(1.10)\end{array}$ & $\begin{array}{l}2.82^{* *} \\
(1.13)\end{array}$ & $\begin{array}{c}5.40^{* * *} \\
(1.96)\end{array}$ & $\begin{array}{c}5.42^{* * *} \\
(1.24)\end{array}$ \\
\hline Age $18-24$ & $\begin{array}{l}-0.01 \\
(3.40)\end{array}$ & $\begin{array}{l}7.83^{*} \\
(4.29)\end{array}$ & $\begin{array}{c}1.05 \\
(5.64)\end{array}$ & $\begin{array}{l}7.62^{* *} \\
(3.15)\end{array}$ \\
\hline Age $25-44$ & $\begin{array}{l}3.18^{*} \\
(1.92)\end{array}$ & $\begin{array}{l}4.64^{*} \\
(2.41)\end{array}$ & $\begin{array}{c}4.91 \\
(3.39)\end{array}$ & $\begin{array}{l}6.86^{* *} \\
(2.90)\end{array}$ \\
\hline Age $45-64$ & $\begin{array}{c}1.28 \\
(1.52)\end{array}$ & $\begin{array}{l}2.40 \\
(2.06)\end{array}$ & $\begin{array}{l}1.27 \\
(2.95)\end{array}$ & $\begin{array}{l}2.35 \\
(2.71)\end{array}$ \\
\hline Married Male & $\begin{array}{l}-1.03 \\
(1.24)\end{array}$ & $\begin{array}{l}-4.67 \\
(7.19)\end{array}$ & $\begin{array}{l}-4.94 \\
(3.31)\end{array}$ & $\begin{array}{l}-10.15 \\
(6.02)\end{array}$ \\
\hline Unmarried Female & $\begin{array}{c}8.25^{* * *} \\
(2.61)\end{array}$ & $\begin{array}{c}9.31^{* * *} \\
(1.71)\end{array}$ & $\begin{array}{c}12.82^{* * *} \\
(2.53)\end{array}$ & $\begin{array}{l}9.37^{* * *} \\
(1.15)\end{array}$ \\
\hline Married Female & $\begin{array}{c}1.96 \\
(1.77)\end{array}$ & $\begin{array}{l}-1.62 \\
(7.52)\end{array}$ & $\begin{array}{l}7.40^{* *} \\
(2.72)\end{array}$ & $\begin{array}{c}0.26 \\
(6.12)\end{array}$ \\
\hline Black & $\begin{array}{c}18.07^{* * *} \\
(6.11)\end{array}$ & $\begin{array}{c}21.51^{* * *} \\
(2.85)\end{array}$ & $\begin{array}{c}17.58^{* * *} \\
(3.83)\end{array}$ & $\begin{array}{c}15.45^{* * *} \\
(1.47)\end{array}$ \\
\hline Hispanic & $\begin{array}{c}2.20 \\
(39.64)\end{array}$ & $\begin{array}{c}16.76^{* * *} \\
(4.37)\end{array}$ & $\begin{array}{c}6.84 \\
(8.93)\end{array}$ & $\begin{array}{c}13.75^{* * *} \\
(2.29)\end{array}$ \\
\hline Some College & $\begin{array}{l}-2.11 \\
(2.98)\end{array}$ & $\begin{array}{c}-10.59^{* * *} \\
(2.23)\end{array}$ & $\begin{array}{l}-3.33 \\
(3.03)\end{array}$ & $\begin{array}{c}-8.81^{* * *} \\
(1.62)\end{array}$ \\
\hline Bachelor's Degree & $\begin{array}{c}-5.27^{* *} \\
(2.59)\end{array}$ & $\begin{array}{c}-15.65^{* * *} \\
(2.22)\end{array}$ & $\begin{array}{c}-15.42^{* * *} \\
(2.86)\end{array}$ & $\begin{array}{c}-19.30^{* * *} \\
(1.25)\end{array}$ \\
\hline $\begin{array}{l}\text { Income Less } \\
\text { Than } \$ 20,000\end{array}$ & $\begin{array}{c}8.01 \\
(8.86)\end{array}$ & $\begin{array}{l}9.43^{* * *} \\
(2.30)\end{array}$ & $\begin{array}{c}11.49^{* *} \\
(5.17)\end{array}$ & $\begin{array}{c}11.11^{* * *} \\
(2.89)\end{array}$ \\
\hline $\begin{array}{l}\text { Income Between } \\
\$ 20,000 \text { and } \$ 40,000\end{array}$ & $\begin{array}{l}7.90^{* *} \\
(3.72)\end{array}$ & $\begin{array}{c}0.78 \\
(1.96)\end{array}$ & $\begin{array}{c}7.12 \\
(4.34)\end{array}$ & $\begin{array}{c}3.73 \\
(2.70)\end{array}$ \\
\hline $\begin{array}{l}\text { Income Between } \\
\$ 40,000 \text { and } \$ 80,000\end{array}$ & $\begin{array}{c}1.29 \\
(1.58)\end{array}$ & $\begin{array}{l}-0.89 \\
(1.37)\end{array}$ & $\begin{array}{c}1.91 \\
(2.55)\end{array}$ & $\begin{array}{l}2.50 \\
(2.43)\end{array}$ \\
\hline $\begin{array}{l}\text { Income Between } \\
\$ 80,000 \text { and } \$ 120,000\end{array}$ & $\begin{array}{c}0.21 \\
(1.52)\end{array}$ & $\begin{array}{l}-2.28 \\
(1.77)\end{array}$ & $\begin{array}{c}0.37 \\
(2.83)\end{array}$ & $\begin{array}{l}-1.96 \\
(2.66)\end{array}$ \\
\hline Unemployed & $\begin{array}{l}10.97 \\
(7.23)\end{array}$ & $\begin{array}{c}4.80 \\
(3.25)\end{array}$ & $\begin{array}{c}8.99 \\
(5.36)\end{array}$ & $\begin{array}{l}3.50^{*} \\
(1.76)\end{array}$ \\
\hline State Unemployment & $\begin{array}{l}1.21^{*} \\
(0.73)\end{array}$ & $\begin{array}{c}0.06 \\
(0.52)\end{array}$ & $\begin{array}{c}2.95^{* * *} \\
(1.14)\end{array}$ & $\begin{array}{c}0.52 \\
(0.52)\end{array}$ \\
\hline Constant & $\begin{array}{c}2.86 \\
(4.54)\end{array}$ & $\begin{array}{c}11.97^{* * *} \\
(4.90)\end{array}$ & $\begin{array}{c}29.51^{* * *} \\
(6.12)\end{array}$ & $\begin{array}{l}27.45 \\
(4.67)\end{array}$ \\
\hline
\end{tabular}

Notes: ${ }^{* * *},{ }^{* *},{ }^{*}$ denote statistical significance at the $1 \%, 5 \%$ and $10 \%$ level respectively with robust standard errors block bootstraped by state in LAD regressions and clustered by state in OLS regressions. 2006: $\mathrm{N}=668$; 2009: $\mathrm{N}=1,859$. Regressions also include minor and missing party, church attendance, union membership, and missing income indicators. The omitted categories are Republicans, age 65+, male, not married, white, 12 years or less of education, $\$ 120,000+$ for income, employed, not in union, and do not attend church. Standard errors block bootstraped by state in LAD regressions and clustered by state in OLS regressions. 


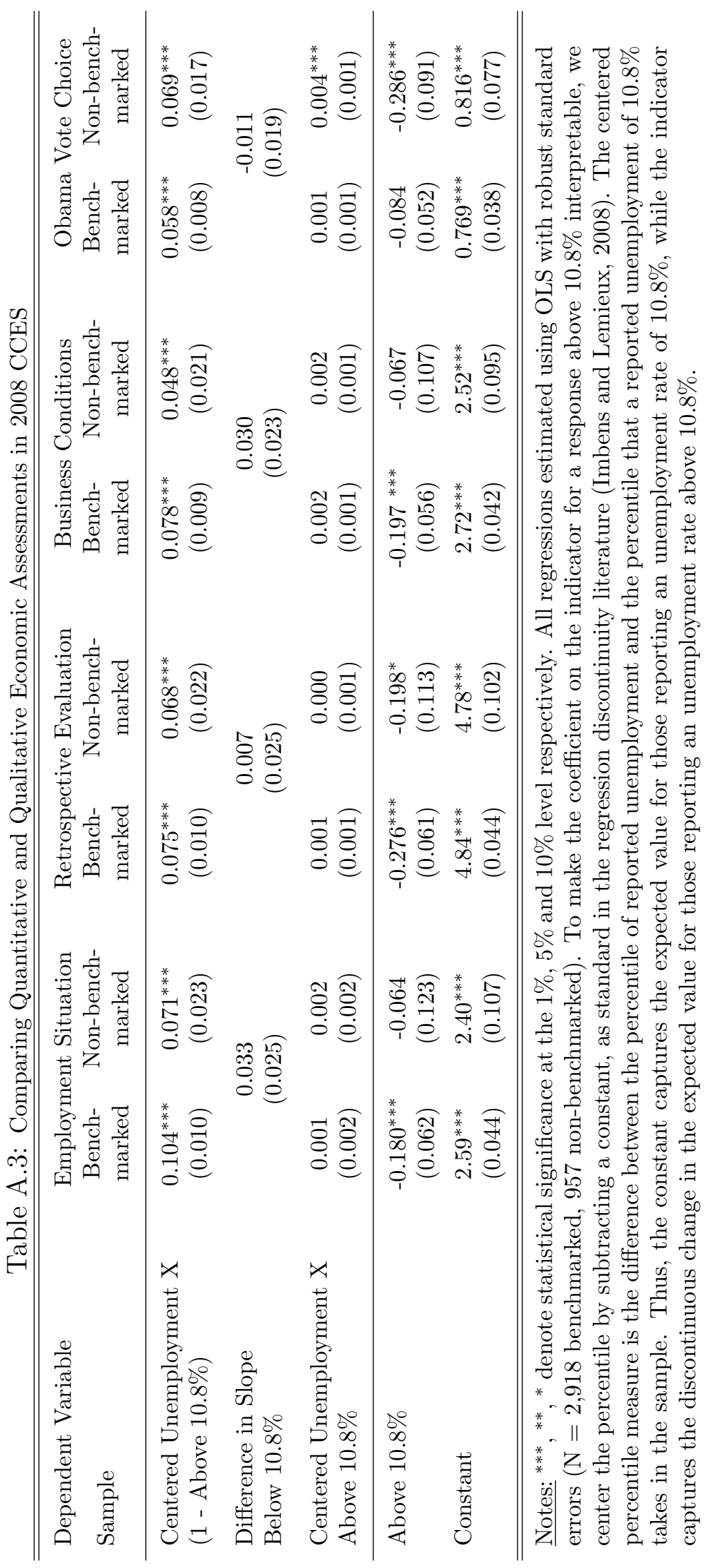

